\title{
The Same Fertility Ideals as in the Country of Origin? A Study of the Personal Ideal Family Size among Immigrant Women in Italy*
}

\author{
Eleonora Mussino, Livia Elisa Ortensi
}

\begin{abstract}
The role of the personal ideal family size for international migrants has rarely been studied in the current debate on fertility and migration in the European context. It is not known to which extent the reduction of fertility observed among immigrants who settle in a country where fertility is lower than in their country of origin is the result of a change in fertility norms among those immigrants. The study of migrants' ideals family size has the potential to shed light on fertility norms without the interference of economic conditions and migration-related disruptive phenomena. Due to the complexity of its migration context, Italy is an interesting destination country for studying changes in migrants' ideal family sizes. This paper uses data from the survey of the Italian National Institute of Statistics (ISTAT) on immigrant families conducted in 2011-12. We compare the personal ideal family size of women of reproductive age with the prevalent norm in their country of origin, applying a multinomial logistic regression analysis. Results show that the country of origin has an important role in the determination of immigrants' ideal family sizes. Women from countries where large families are the ideal are more likely to show a lower personal ideal family size compared to their non-migrant co-nationals, while women from countries where two children are considered ideal mostly share the same norm. The occurrence of fertility preferences expressed in a non-numeric form (e.g. "Up to God") changes between women with different countries of origin. This study confirms that conformity with the ideal of the country of origin is more likely among women who migrated as adults. At the same time, the number of years spent in the destination country is not significantly associated with a shift away from the norms prevalent in the country of origin. Finally, female empowerment and gender equity show their effects mainly on the reduction of non-numeric responses.
\end{abstract}

Keywords: Ideal number of children · Fertility · Migrants · Italy · Gender Norms

\footnotetext{
This article belongs to a special issue on migrant fertility.
} 


\section{Introduction}

The importance of norms has long been recognised in both sociology and demography (Bulatao et al. 1983). Many scholars assigned a key role to fertility norms in explaining essential processes such as the historical fertility transition and the process of fertility decline in developing countries (Liefbroer/Billari 2010). Among fertility norms, personal ideal family size is considered to be a good indicator of individual values and attitudes towards childbearing, though it has been established that it cannot be used to predict actual or final fertility (Testa/Grilli 2006). Testa/Grilli (2006) emphasised the lack of scholarly reflection on the personal ideal family size of native populations in Europe. This same conclusion can be drawn today regarding the study of the personal ideal family size of international migrants.

In the last decades, migration flows have determined the relocation of a considerable number of women who grew up and were socialised in a context where fertility ideals are remarkably different from those observed in their country of destination. Current theories about the migration-fertility nexus consider the role of fertility ideals as key, but due to the scarcity of specific data, research has so far mostly been based on migrants' actual behaviour. While some migrants move between areas that share similar ideals of relatively small families, others move from countries at different stages of the demographic transition. Thus they may have been socialised in contexts where large families are common and idealised (Fargues 2007). In the latter case, migrants may show fertility ideals and preferences similar to natives of the country of destination because they belong to select groups sharing ideals more similar to those in destination countries than in their origin country, a position known in the literature as the selection hypothesis (White et al. 1995). Alternatively, they may have different ideals upon arrival and then converge or adapt to the fertility norm of the country of settlement (Rindfuss 1976; Nauck 1987; Mayer/Riphahn 2000). Finally, they may instead preserve their ideals while showing fertility behaviour similar to destination-country natives due to transformations of their living conditions, including constraints and trade-offs typically related to migration - such as weak labour market attachment - which have an impact on both the timing and the number of births (Fargues 2007). However, the extent to which the reproductive behaviour observed among immigrants is consistent with fertility norms or instead differs as a consequence of financial restrictions or other disruptive phenomena is unknown. The study of migrants' ideals has the potential to shed light on fertility norms without the interference of migration-related disruptive phenomena.

The few existing studies on the ideal family size of foreign-born citizens, which are mostly descriptive in their approach, show the presence of broad differences among ethnic or migrant communities, identified as people who share the same foreign background. Individual factors such as religion, education, and the number of siblings emerge as significant in shaping the ideal number of children in Great Britain, France, and Germany (Penn/Lambert 2002).

To fill this gap in the literature, we compare individual personal ideal family size among migrant women in Italy with the prevalent norms in the respective countries of origin as a proxy for the normative environment in which migrants were social- 
ised. We also focus on the role of gender equity and female empowerment among migrants, as several studies have underlined a direct relationship between these two dimensions and fertility in both developed and developing countries (Genereux 2007; Arpino et al. 2015; Blau 2015), which may also significantly shape migrant fertility (Kulu et al. 2017).

Even though Italy has a less expansive history as a country of immigration than other European states do, six million of its residents - 10 percent of the total population in 2017 - are foreign-born (Eurostat 2018). Due to the complexity of its migration context (King 2000), which is characterised by the presence of migrant communities from countries with different fertility behaviours, Italy emerges as an interesting country in the study of ideal family sizes of migrants. What furthermore makes Italy a compelling case is the persistence of the two-child family norm among native Italians, despite having de facto "lowest-low" fertility rates (Testa 2012). This paper aims to answer the following research questions: How many children would immigrant women in Italy like to have? Do their preferences differ from the norms in their origin country? And what is the impact of country of birth, migration-related characteristics, female empowerment, and gender equity? To address these questions, we analysed data on 7,307 immigrant women of reproductive age residing in Italy in 2011-12 from 101 countries $^{1}$ and compared their personal ideal family size with the national average ideal size in their origin country.

\section{Background}

\subsection{Actual fertility, family size preferences, and ideals}

The analysis of fertility among migrants has so far been mostly based on data related to their actual behaviour, typically the number of children born after migration (e.g. Ortensi 2015), the transition to different parities (e.g. Andersson 2004; Milewski 2010; Mussino/Strozza 2012a, 2012b), or the contribution of migrants to the total number of births (Sobotka 2008). Differences between cultural norms in the countries of birth and destination have also been studied by looking at immigrants' ac-

1 Africa: Algeria, Angola, Benin, Burkina Faso, Burundi, Cameroon, Cape Verde, Democratic Republic of Congo, Egypt, Eritrea, Ethiopia, The Gambia, Ghana, Guinea, Ivory Coast, Kenya, Madagascar, Mali, Morocco, Nigeria, Republic of Congo, Senegal, Sierra Leone, South Africa, Togo, Tunisia.

Americas: Argentina, Bolivia, Brazil, Canada, Chile, Colombia, Dominican Republic, Ecuador, El Salvador, Guatemala, Honduras, Mexico, Peru, USA, Venezuela.

Asia and Oceania: Armenia, Australia, Azerbaijan, Bangladesh, China, Georgia, India, Indonesia, Iran, Iraq, Israel, Japan, Jordan, Kazakhstan, Kyrgyzstan, Pakistan, Philippines, South Korea, Sri Lanka, Thailand, Turkey, Uzbekistan, Vietnam.

Europe: Albania, Austria, Belarus, Belgium, Bosnia-Herzegovina, Bulgaria, Croatia, Czech Republic, Denmark, Estonia, Finland, France, Germany, Greece, Hungary, Ireland, Kosovo, Latvia, Lithuania, Luxemburg, Macedonia, Moldova, Montenegro, Netherlands, Norway, Poland, Portugal, Romania, Russia, Serbia, Slovakia, Slovenia, Spain, Sweden, Switzerland, UK, Ukraine. 
tual fertility (Algan et al. 2012). Cultural adaptation has been conceptualised as the convergence to the fertility norms of the destination country (Andersson 2004).

The selection hypothesis argues that many migrants' behaviour may indeed not change at all - rather, people who choose to migrate in the first place are a self-selected group, whose fertility preferences are different - usually lower - than than the general average in their country of origin (Kulu 2005). The maintenance of country of origin fertility behaviors after migration has been interpreted in the logic of the socialisation hypothesis, which similarly builds on the premise that the fertility behaviour of migrants primarily reflects the fertility preferences dominant in their childhood environment (Kulu 2005; Baykara-Krumme/Milewski 2017). Nevertheless, it is widely acknowledged that the timing and the number of births are not only shaped by norms and preferences, but also reflect constraints and inequalities, such as precarious economic conditions, difficulties in reconciling family life and demanding jobs, the unavailability of a suitable partner, poor health, infertility, or unplanned pregnancies (Martin 2004; Philipov/Bernardi 2011; Sedgh et al. 2014; Finer/Zolna 2016). In the case of migrants, the relation between norms, preferences, and actual fertility is even more complicated because - as with all life course events - fertility behaviours are sensitive to the act of migration (Holland/de Valk 2013). Consequently, the study of migrants' ideals, is crucial to explain the possible change in fertility norms without the interference of personal, financial or health-related trade-offs and migration-related disruptive phenomena.

Differently from the analysis of actual and intended fertility, the study of concepts such as the "ideal family size", the "personal ideal family size", and the "desired/preferred family size" builds on evaluations made under "ideal conditions" (Philipov/Bernardi 2011), and it has been shown that societal norms concerning demographic behaviours are relevant, even in a society where the individualisation process is fairly advanced (Liefbroer/Billari 2010). Fertility ideals and desires have nevertheless been subject to criticism for being relatively "soft", abstract, and poorly defined concepts (Toulemon 2001; van de Kaa 2001; Quesne/-Vallée/Morgan 2003; Sobotka/Beaujouan 2014). However, family size desires are conceptually and empirically distinct from ideals: desires reflect more "internal" factors, such as motivations, attitudes, and beliefs and have, therefore, been considered as a personal norm (Testa/Grilli 2006; Kuhnt et al. 2017). Desires are often uncertain and subject to change over the life course in response to new experiences and conditions (Thomson 2015). Personal ideals have instead been interpreted as reflecting the normative context; they are shaped by the larger society after predominant societal pronatalist or antinatalist norms and, therefore, change more slowly than desires do (Trent 1980; Testa/Grilli 2006; Thomson 2015).

The analysis of migrants' personal ideal family size is not a trivial one: analyses of social distance between migrant groups and natives are at the core of academic and public discourses (Holland/de Valk 2013). While integration in some sectors such as the labour market and education can be relatively fast, changes in the private domain and the normative sphere, to which life course events are deeply related, are slower to occur and may require far more than a generation to be internalised (Gordon 1964; Lesthaeghe 2002). Ideals have the potential to provide insight into 
the balance between the persistence of norms from the country of origin and the processes of family change and socialisation after migration.

The few studies on fertility ideals carried out on ethnic groups or migrants in different destination countries suggest the existence of differences between different ethnic groups in both the preferred timing for family formation and the ideal family size (Penn/Lambert 2002; Holland/de Valk 2013). However, socialisation seems to play an important role. In the Netherlands, de Valk (2013) found intergenerational differences among all ethnic groups: usually children prefer smaller families than their parents did.

Penn and Lambert (2002), who conducted a cross-national analysis of the ideal number of children among different ethnic groups and nationalities, found substantial differences between ethnic groups in Britain, Germany, and France. Indian and Pakistani respondents in Britain expressed significantly larger ideal families than native Brits; at the same time Maghrebians in France also valued large families, but the difference to French natives was less evident. The study also found a preference for ideal families of two children among Turkish and former-Yugoslav migrants in Germany, and no significant differences with German natives. These findings suggest that ethnic group differences are essential to understanding fertility norms among migrants.

\subsection{What determines the ideal family size? Evidence from previous research}

Previous research in the fertility domain, mainly building on evidence from Western countries' natives, has suggested a link between ideal family size and a set of potential explanatory variables. Age is one of them: attitudes and norms are more relevant at the beginning of the reproductive career, while perceived behavioural control plays a stronger role after the birth of the first child (e.g. Testa/Grilli 2006; Mills et al. 2008; Billari et al. 2009). Age also has the potential to capture cohort effects and shape ideal family size according to respondents' own experiences of childbearing and parenthood (Weston et al. 2005; Kuhnt et al. 2017). Some studies have suggested that fertility ideals are adjusted in line with the size of the respondent's current number of children; for this reason, it is important to control for this item (Weston et al. 2005; Kuhnt et al. 2017).

Family size ideals are also likely influenced by the respondent's socioeconomic status. The influence of socioeconomic status here does not take hold through economic limitations that may affect childbearing, because ideals by definition are expressed regardless any current circumstance (/acovou/Tavares 2011; Kuhnt et al. 2017). Rather, the role of socioeconomic deals with social norms of childbearing found within the social networks or categories which the respondents belong to and that are considered as their reference groups (Liefbroer/Billari 2010).

Partnership status does not seem to alter fertility ideals (Kuhnt et al. 2017). Ideals are consequently more stable than intentions or desires, because they are related to a social norm rather than to a shorter-term personal preference or contingencies (Thomson 2015). 
The role of education also needs to be discussed when examining fertility ideals. While in developing countries, higher education is usually related to lower ideal fertility (Doepke/Tertilt 2018), in the European setting, a diverging trend has occasionally been observed. In some countries, a positive relationship between education and fertility has been observed after experiencing a period of low fertility related to educational expansion (OECD 2016). Education and human capital are often interpreted as a proxy for female empowerment, according to the idea that more educated women have more bargaining power in marriage (Mills et al. 2008; Doepke/ Tertilt 2018). Higher levels of education allow women to question traditional roles (McDonald 2006) and are often associated with a more equal division of household chores (e.g. Mencarini/Tanturri 2004). Scholars have repeatedly pointed out a significant and complex link between unbalanced gender roles (in the form of unequal divisions of household labour) and fertility intentions and behaviour (Mills 2010; Tazi-Preve et al. 2004; Neyer et al. 2013). Consistently, gender equity, which captures perceptions of fairness rather than the strict equality of observed outcomes (Mc Donald 2013), may significantly impact fertility ideals.

However, the results of the few studies that have considered the link between female empowerment and the ideal number of children in developing countries are mixed. A 2002 study based on Demographic and Health Survey (DHS) data in Eritrea found that women having the final say in decisions regarding day-to-day household purchases was associated with a smaller ideal family size (Woldemicael 2009). At the same time, a more recent study based on data on Guinea, Mali, Namibia and Zambia found women's empowerment (measured as participation in household decision making, attitudes towards domestic violence, and attitudes toward refusing sex with one's husband) is not consistently associated with a desire for smaller families (Upadhyay/Karasek 2012).

Job participation is similarly related to gender roles: Homemaker mothers may be more likely to have traditional attitudes than employed mothers (Fan/Marini 2000; Zuo/Tang 2000; Bolzendahl/Myers 2004), but, more generally, gender equality and fertility have a U-shaped relationship (e.g. McDonald 2013; Upadhyay et al. 2014; Esping-Andersen/Billari 2015). Religion has also proven to be an important factor relating to fertility. In many contexts, women who describe religion as "very important" have higher fertility than others, especially those who declare they are unaffiliated with any religion (Frejka/Westoff 2008; Berghammer 2012; Peri-Rotem 2016). However, just as for education and female labour force participation, it has been argued that the fertility-religion nexus expresses a widespread association between religiosity and family behaviour, rather than specifically pronatalist views held in specific religions. In fact, it appears that factor at play is less religiosity per $s e$, but rather certain more specific notions of family life often associated with religiosity, which include ideas about the importance of marriage and parenthood, the acceptability of non-marital sexual relations, and gender roles (Hayford/Morgan 2008).

Previous studies on migrants have found that ideal family sizes are different among different ethnic groups (Penn/Lambert 2002; de Valk 2013). However, for first-generation migrants, age at arrival emerges as a crucial dimension. Sociali- 
sation studies assert that family (size) values formed in late childhood and early adolescence are retained throughout life (e.g. Westoff/Potvin 1967; Kulu 2005). According to this theory, people who migrated after having spent their childhood and early adolescence in their country of origin should preserve family ideals typical of the countries where they were socialised, even if after migration they may choose adaptive strategies to deal with the new context of settlement. By contrast, according to classical theories on immigrant assimilation (Gordon 1964), a long residence abroad implies a growing influence of the dominant family formation patterns in the destination country, which may also be internalised as family ideals (Holland/de Valk 2013). The relation between socialisation and adaptation at the individual level, therefore, may be associated to immigrants' duration of residence in the settlement country (Lieberson/Waters 1988; Alba/Nee 2003).

A factor potentially related to the effect of migration on ideal formation is language, which is a functional factor positively associated with aspects of social integration at the destination country (Ager/Strang 2008; Kearns/Whitley 2015). To be fluent in the host country's language is a precondition for communication across cultural boundaries (Statham/Tillie 2016). However, studies on the effect on internalisation of norms are discordant. When analysing the association with fertility, Unger and Molina (1997) identified language as an influential factor amongst Hispanic women in the United States: Those who spoke Spanish at home with their mother were far more likely to have a higher personal ideal number of children (particularly sons) than those who spoke English. By contrast, Penn and Lambert (2002) found no support for this "cultural" hypothesis in their study in Great Britain, France, and Germany.

A final remark is needed about the occurrence of non-numerical responses. Women sometimes provide their ideal number of children in terms of words rather than numbers, for example, "it's up to God", "as many as possible", or simply "I don't know". The occurrence of this kind of answer has recently been declining in fertility surveys, suggesting that "numeracy about children" (Van de Walle 1992) is increasing across the developing world. A recent study based on DHS carried out in 32 countries in Asia, Latin America, and sub-Saharan Africa underlined that non-numerical responses are indicative of high fertility and pre-transitional contexts. Their occurrence declines with lower fertility rates. At the individual level, non-numerical responses are indirectly related to higher education and fertility-specific knowledge (Frye/Bachan 2017). Other studies suggest that women who provide non-numeric responses share traditional pronatalist cultural norms that imply preferences for "many" children rather than encouraging women to select a specific number as their ideal (Olaleye 1993). Other scholars have suggested that non-numeric responses are an indication of women's perceived lack of control over their fertility (Hayford/ Agadjanian 2011; Van de Walle 1992).

\subsection{Working hypotheses}

Based on the literature discussed above, the hypotheses tested in this study are the following: 
- H1: The personal ideal number of children is associated with the ideal number of children in the country of origin ( $\mathrm{H} 1 \mathrm{a})$, even when we control for migratory and socio-economic factors (H1b).

- H2: Consequently, people arriving as adults are more likely to have a personal ideal number of children similar to that of their origin country, compared to those who migrated as children or young adults.

- H3: At the same time, a long and uninterrupted presence in Italy might be associated with a deviation from the prevalent norms of the country of origin.

- H4: Higher levels of female empowerment (education and labour market participation) and support for gender equity imply higher numeracy about children, and therefore a lower proportion of non-numeric responses.

In summary, this study analyses ideal family sizes of migrant women in Italy and how they differ from the prevalent norms in their countries of origin, thereby underlining the role of the country of origin, migratory characteristics, and gender roles in fertility ideals - three specific points that are currently under-researched in the field of fertility and migration.

\section{Empirical analyses}

\subsection{Measures of fertility intentions and attitudes}

The norms observed in migrants' countries of origin has been defined as the mean ideal family size observed in national surveys available worldwide on this topic. This means that we must rely on different sources and slightly different wording of questions on the ideal family size in the country of origin.

The first survey that included a question on ideal family size was carried out in 1936 (Blake 1966). Since then, hundreds of surveys around the world have collected information about family ideals in different countries and contexts (Sobotka/Beaujouan 2014). The 2011-12 Italian National Institute of Statistics' (ISTAT) survey "Social condition and integration of foreign citizens" formulated the question to measure personal ideal family size as follows: "How many children would you like to have in your life?"

To account for the personal ideal family size norm in the immigrants' countries of origin, we assembled information from different surveys. Unfortunately, not all the surveys were run in the same year, so, in order to allow comparability with our survey and between countries, we rely on the most current version available. In these surveys, the questions did not always focus on the personal ideal family size - some focused on the general ideal family size (e.g. "What do you think is the ideal number of children for a family?"). To provide maximum comparability with the ISTAT survey, we collected the information on personal ideal family size when it was possible; otherwise, we used the information on general family size ideals (Table 1).

In a previous study, Testa (2012: 9) compared the relationship between responses to general and personal ideal family size using the 2011 Eurobarometer. She found a very close agreement between these two dimensions (see also Sobotka/ 
Tab. 1: Measures of personal ideal family size from different surveys used to calculate the norm in the country of origin

\begin{tabular}{|c|c|c|c|}
\hline Survey & Question & Measure & Countries \\
\hline Eurobarometer (2011) & $\begin{array}{l}\text { [And] for you } \\
\text { personally, what would } \\
\text { be the ideal number of } \\
\text { children you would like } \\
\text { to have or would have } \\
\text { liked to have had? }\end{array}$ & $\begin{array}{l}\text { Personal ideal } \\
\text { family size }\end{array}$ & $\begin{array}{c}\text { Austria, Belgium, } \\
\text { Bulgaria, Czech Republic, } \\
\text { Cyprus, Estonia, Finland, } \\
\text { France, Germany, Greece, } \\
\text { Ireland, Latvia, Lithuania, } \\
\text { Luxemburg, Nederland, } \\
\text { Poland, Portugal, United } \\
\text { Kingdom, Romania, } \\
\text { Slovakia, Spain, Sweden, } \\
\text { Hungary }\end{array}$ \\
\hline $\begin{array}{l}\text { World Values Survey } \\
(1981-2008)\end{array}$ & $\begin{array}{l}\text { What do you think is } \\
\text { the ideal size of a family } \\
\text { - how many children, } \\
\text { if any? }\end{array}$ & $\begin{array}{l}\text { General ideal } \\
\text { family size }\end{array}$ & $\begin{array}{c}\text { Algeria, Belarus, Bosnia- } \\
\text { Herzegovina, El Salvador, } \\
\text { Iran, Iraq, Macedonia, } \\
\text { Moldova, Montenegro, } \\
\text { Serbia }\end{array}$ \\
\hline \multirow{2}{*}{$\begin{array}{l}\text { Demographic Health } \\
\text { Survey (DHS), } \\
\text { Reproductive Health } \\
\text { Survey (RHS) 1997- } \\
\text { 2011; 2003 UNFPA } \\
\text { Demographic, Social } \\
\text { and Reproductive } \\
\text { health situation in } \\
\text { Kosovo (2003); Multiple } \\
\text { Indicators Cluster } \\
\text { Survey (MICS) 2006- } \\
\text { 2016, PAP-FAM } 2001\end{array}$} & $\begin{array}{l}\text { Women with children: } \\
\text { If you could go back } \\
\text { to the time you did not } \\
\text { have any children and } \\
\text { could choose exactly } \\
\text { the number of children } \\
\text { to have in your whole } \\
\text { life, how many would } \\
\text { that be? }\end{array}$ & & \multirow{2}{*}{$\begin{array}{c}\text { Albania, Angola, } \\
\text { Armenia, Azerbaijan, } \\
\text { Bangladesh, Benin, } \\
\text { Bolivia, Brazil, Burkina } \\
\text { Faso, Burundi, } \\
\text { Cameroon, Cape } \\
\text { Verde, Colombia, Ivory } \\
\text { Coast, Dominican } \\
\text { Republic, Ecuador, } \\
\text { Egypt, Philippines, } \\
\text { Eritrea, Ethiopia, The } \\
\text { Gambia, Georgia, Ghana, } \\
\text { Jordan, Guatemala, } \\
\text { Guinea, Honduras, India, } \\
\text { Indonesia, Kazakhstan, } \\
\text { Kenia, Kirgizstan, } \\
\text { Kosovo, Madagascar, } \\
\text { Mali, Morocco, Nigeria, } \\
\text { Pakistan, Peru, Senegal, } \\
\text { Sierra Leone, Sri Lanka, } \\
\text { South Africa, Thailand, } \\
\text { Togo, Tunisia, Ukraine, } \\
\text { Uzbekistan, Vietnam }\end{array}$} \\
\hline & $\begin{array}{l}\text { Childless women: If you } \\
\text { could choose exactly } \\
\text { the number of children } \\
\text { to have in your whole } \\
\text { life, how many would } \\
\text { that be? }\end{array}$ & $\begin{array}{l}\text { Personal ideal } \\
\text { family size }\end{array}$ & \\
\hline $\begin{array}{l}\text { International Social } \\
\text { Survey } 2012\end{array}$ & $\begin{array}{l}\text { All in all, what do } \\
\text { you think is the ideal } \\
\text { number of children for } \\
\text { a family to have? }\end{array}$ & $\begin{array}{l}\text { General ideal } \\
\text { family size }\end{array}$ & $\begin{array}{c}\text { Argentina, Australia, } \\
\text { Canada, Chile, China, } \\
\text { South Korea, Croatia, } \\
\text { Japan, Israel, Mexico, } \\
\text { Norway, Russia, USA, } \\
\text { Switzerland, Turkey, } \\
\text { Venezuela }\end{array}$ \\
\hline
\end{tabular}

Source: Overview based on Eurobarometer, World Values Survey, Demographic Health Survey (DHS), Reproductive Health Survey (RHS) UNFPA Demographic, Social and Reproductive health situation; Multiple Indicators Cluster Survey (MICS), PAP-FAM and International Social Survey. 
Beaujouan 2014). We rely on the original data set in the case of the Eurobarometer and the Demographic Health Survey (DHS), while for the countries that were not included in these two surveys, we collected the information from other sources. We report the original questions for comparison in Table 1. For each country survey we calculated the mean ideal family size applying individual survey weights, according to Sobotka and Beaujouan's (2014) approach. Data are always provided for women aged 15-49 except for countries covered by the World Values Survey, which is based on women aged 18-49.

\subsection{Data and methods}

This paper uses data from the ISTAT survey "Social condition and integration of foreign citizens". The survey was conducted in 2011-12 with families that have at least one member with foreign citizenship. Families were randomly sampled from the civil registry. The final sample survey is made up of 12,000 households in $800 \mathrm{mu}-$ nicipalities of different demographic sizes. For this study, only foreign-born women were selected from the original sample. Our final sample consists of 7,307 foreignborn women aged 15 to 49 . They come from 101 countries for which information on the individual family size is available. About 37 percent of the foreign-born women in the sample were childless, 27 percent had 1 child, 26 percent had 2 children, and the remaining 10 percent had 3 or more children.

We study the personal ideal family size by comparing the individual ideal number in Italy with the norm in the country of origin, by different origin groups. We plot and map personal ideal family size in Italy and in the countries of birth of migrant women.

Through a set of multinomial logistic regression analyses, we investigate the factors that influence the (dis)agreement between the personal ideal family norm and the norm in the origin country. (Dis)agreement is categorised into 5 groups: the same personal ideal number of children as in the country of origin $(-0.5<x \leq 0.5)$; a lower personal ideal number of children than in the country of origin $(x \leq-0.5)$; a larger personal ideal number of children than in the country of origin $(x>0.5)$; "as many as I may have" (as this category is generally translated as "Up to God", we will also use this phrase); and "I don't know". The reference category is the one in which the personal ideal family size matches the country of origin norm. To show the substantive and practical significance of the findings, we present population marginal means (e.g. Searle et al. 1980; Williams 2012) while holding the covariates fixed at the population means for the main independent variables. Additional results are in Table A3 in the Appendix.

Our study focuses on the (dis)agreement between the personal ideal number of children and the mean value observed in the country of origin. In analysing our data, we control for demographic and socioeconomic factors. To test hypotheses $\mathrm{H} 1 \mathrm{a}, \mathrm{H} 1 \mathrm{~b}, \mathrm{H} 2$ and $\mathrm{H} 3$, in addition to country of birth, ${ }^{2}$ we examine the age at migra-

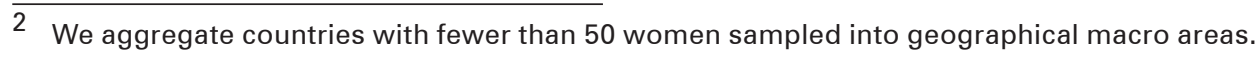


tion and distinguish if the women arrived before age 16, between 16 and 20, or after age 20; time since migration (up to 5 years in Italy, between 6 and 10, more than 10 years); and the stability of their presence (stable/uninterrupted vs. unstable/discontinuous). To test hypothesis $\mathrm{H} 4$ we examine labour market participation, education, and gender equity ${ }^{3}$ (no support for gender equity vs. support for gender equity). Additionally, we control for the frequency of religious-service attendance (sometimes, never, often) and Italian proficiency (good vs. bad) (see Appendix Table A1 for details).

Because one of the aims of our study is to evaluate the importance of the country of birth for the difference between the personal ideal number of children in Italy versus the origin norm, we compare the estimation power of the models using Akaike's information criterion (AIC) and the Bayesian information criterion (BIC). These two tests allow for comparing non-nested models if the results come from the same data (results are in Table A2 in the Appendix).

\section{$4 \quad$ Results}

\subsection{How many children would immigrant women in Italy like to have?}

Figure 1 illustrates the mean number of children that immigrant women in Italy would like to have, by country of origin. Among the migrants residing in Italy, the majority of groups would like to have 2 children. The mean ideal personal number of children for women from Ireland, Israel, The Gambia, Pakistan, Bolivia, Guinea, Senegal, and Burkina Faso is 3, and for women from the Democratic Republic of Congo and Mali, it is more than 4. The average for most of the women from Eastern Europe (Latvia, Belarus, Estonia, Ukraine, Czech Republic, Poland, Bulgaria, Georgia, Romania, Croatia, Lithuania, Slovenia), Southern Europe (Greece, Portugal), Africa (South Africa, Madagascar, Angola, Ethiopia), the Middle East and Asia (Iraq, Iran, Vietnam, Japan, Thailand, Indonesia, Kazakhstan), Western Europe (Austria, Switzerland, Belgium, Denmark), and the Americas (Honduras, Venezuela, Brazil, Mexico) is less than 2 children. The data for Italian natives - 1.95 according to the 2011 Eurobarometer survey - is also included in Figure 1.

\subsection{Do their preferences differ from the norms in their origin country?}

For each country of origin, or area (in the case of small communities in the sample), Table 2 shows the percentage of women who express same, lower or larger personal ideal numbers of children than their country of origin average, and the incidence

3 We measure equity by agreement ("completely agree") with the statement that men should help with domestic work. We tested different indicators; the survey contains seven questions related to gender norms. We ran separate models for each indicator and while the direction of the coefficients was the same for each indicator, the significance level and the contribution in the model was significantly higher for the selected indicator. 
Fig. 1: Personal ideal family size of immigrants to Italy by country of origin

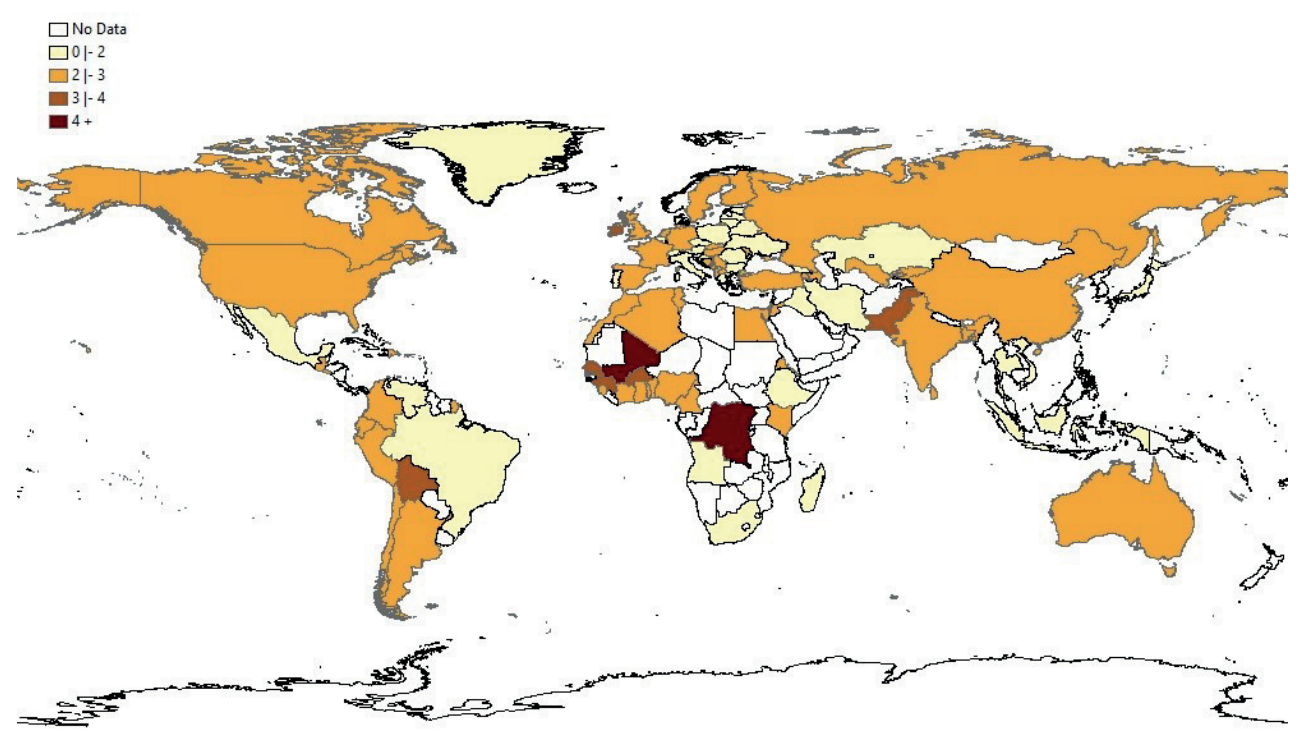

Source: Own design based on ISTAT survey "Social condition and integration of foreign citizens" 2011-12.

of non-numerical answers. 32.8 percent of the women in the sample have the same ideal number of children as the norms in their country of origin, while 33.5 percent have a lower ideal. Women who have a larger ideal number of children than their non-migrant peers make up only 11.9 percent of the sample.

Non-numerical responses indicating an undefined desired number of children ( 7.5 percent of the sample) are most common among women from Nigeria, Senegal and Sri Lanka. At the same time, women who are undecided (14.3 percent of the sample) are most common among those born in Macedonia, Nigeria and Bulgaria.

Figure 2 shows the association between the prevalent norm among emigrants and non-migrants by origin country. We plot the mean personal ideal number of children in Italy for the main migrant groups (i.e. those with more than 50 women in the sample) alongside the mean calculated among women aged 15-49 in the respective origin countries.

The points near the $45^{\circ}$ line represent the migrant groups living in Italy that have a preference close to the norms in their origin country. The greater the distance between the points and the line, the higher the difference in the expressed ideal family size between the immigrant group in Italy and their counterparts in the origin country. Few immigrant groups seem to share the same exact preference as that of their country of origin; namely, Romania, Bulgaria, and Ukraine have a desired number of children below 2 in both groups and Bosnia Herzegovina 2.5. Most of the groups living in Italy report a lower personal ideal family size than the one in their origin country, with the largest distances observed for women from Nigeria, Senegal, Pakistan, and Ghana, where the mean ideal family size at the national level is above 4 
Tab. 2: Personal ideal number of children compared to the country of origin average norm by country of origin and areas. Percentages and absolute sample sizes $(N=7,307)$

\begin{tabular}{|c|c|c|c|c|c|c|}
\hline & $\begin{array}{l}\text { Lower } \\
\text { Personal } \\
\text { ideal } \\
\text { family size }\end{array}$ & $\begin{array}{c}\text { Same } \\
\text { Personal } \\
\text { ideal } \\
\text { family size }\end{array}$ & $\begin{array}{c}\text { Larger } \\
\text { Personal } \\
\text { ideal } \\
\text { family size }\end{array}$ & Up to God & $\begin{array}{l}\text { I don't } \\
\text { know }\end{array}$ & $\begin{array}{l}\text { Absolute } \\
\text { numbers }\end{array}$ \\
\hline Bulgaria & 12.2 & 52.2 & 7.7 & 8.0 & 19.9 & 85 \\
\hline India & 6.5 & 50.4 & 19.2 & 11.5 & 12.4 & 156 \\
\hline Russia & 19.9 & 47.4 & 16.6 & 7.2 & 8.9 & 85 \\
\hline EU15 and ODCs ${ }^{1}$ & 21.5 & 44.9 & 12.7 & 7.2 & 13.7 & 204 \\
\hline Poland & 20.3 & 44.8 & 10.3 & 9.7 & 14.9 & 263 \\
\hline Germany & 13.4 & 44.6 & 23.6 & 6.6 & 11.8 & 58 \\
\hline Romania & 19.8 & 44.2 & 14.0 & 6.7 & 15.3 & 1808 \\
\hline Bangladesh & 5.0 & 43.1 & 29.2 & 9.0 & 13.7 & 84 \\
\hline Brazil & 21.3 & 42.8 & 18.4 & 5.2 & 12.3 & 126 \\
\hline Ukraine & 25.7 & 41.4 & 10.1 & 4.1 & 18.7 & 384 \\
\hline Other Latin America & 27.5 & 41.0 & 14.5 & 8.5 & 8.5 & 127 \\
\hline Peru & 15.8 & 37.5 & 27.8 & 2.6 & 16.3 & 187 \\
\hline Other Europe & 31.8 & 36.0 & 9.9 & 5.4 & 16.9 & 294 \\
\hline France & 18.4 & 34.9 & 31.4 & 3.2 & 12.1 & 79 \\
\hline China & 13.0 & 32.4 & 30.4 & 10.7 & 13.5 & 267 \\
\hline Tunisia & 39.8 & 32.0 & 5.6 & 8.2 & 14.4 & 109 \\
\hline Dominican Republic & 38.6 & 31.1 & 13.5 & 3.1 & 13.7 & 69 \\
\hline Morocco & 39.7 & 25.7 & 10.9 & 10.8 & 12.9 & 618 \\
\hline Macedonia & 36.4 & 24.8 & 5.8 & 11.4 & 21.6 & 117 \\
\hline Kosovo & 44.0 & 21.7 & 11.9 & 10.8 & 11.6 & 75 \\
\hline Other Asia & 53.8 & 19.5 & 7.8 & 10.1 & 8.8 & 201 \\
\hline Ghana & 62.9 & 18.8 & 3.1 & 9.7 & 5.5 & 57 \\
\hline Albania & 57.3 & 18.7 & 5.1 & 7.3 & 11.6 & 673 \\
\hline Senegal & 52.2 & 17.5 & 5.6 & 13.2 & 11.5 & 67 \\
\hline Other Africa & 53.9 & 17.2 & 6.6 & 5.1 & 17.2 & 299 \\
\hline Moldova & 64.1 & 16.4 & 2.8 & 4.7 & 12.0 & 269 \\
\hline Ecuador & 59.8 & 15.8 & 6.3 & 3.1 & 15.0 & 167 \\
\hline Philippines & 57.5 & 11.7 & 5.8 & 8.3 & 16.7 & 187 \\
\hline Sri Lanka & 61.4 & 11.5 & 1.6 & 13.0 & 12.5 & 105 \\
\hline Nigeria & 60.3 & 3.1 & 0.0 & 16.0 & 20.6 & 86 \\
\hline Total & 33.5 & 32.8 & 11.9 & 7.5 & 14.3 & 7307 \\
\hline
\end{tabular}

1 Australia, Austria, Belgium, Canada, Denmark, Finland, Greece, Ireland, Israel, Luxembourg, Netherlands, Norway, Portugal, Sweden, Switzerland, United Kingdom, United States.

Source: Own calculations based on ISTAT survey "Social condition and integration of foreign citizens" 2011-12 and nationals surveys (most recent year available). Frequencies are ordered by having the same preferences. 
Fig. 2: Personal ideal family size in Italy compared to the country of origin norm for groups with at least 50 women sampled

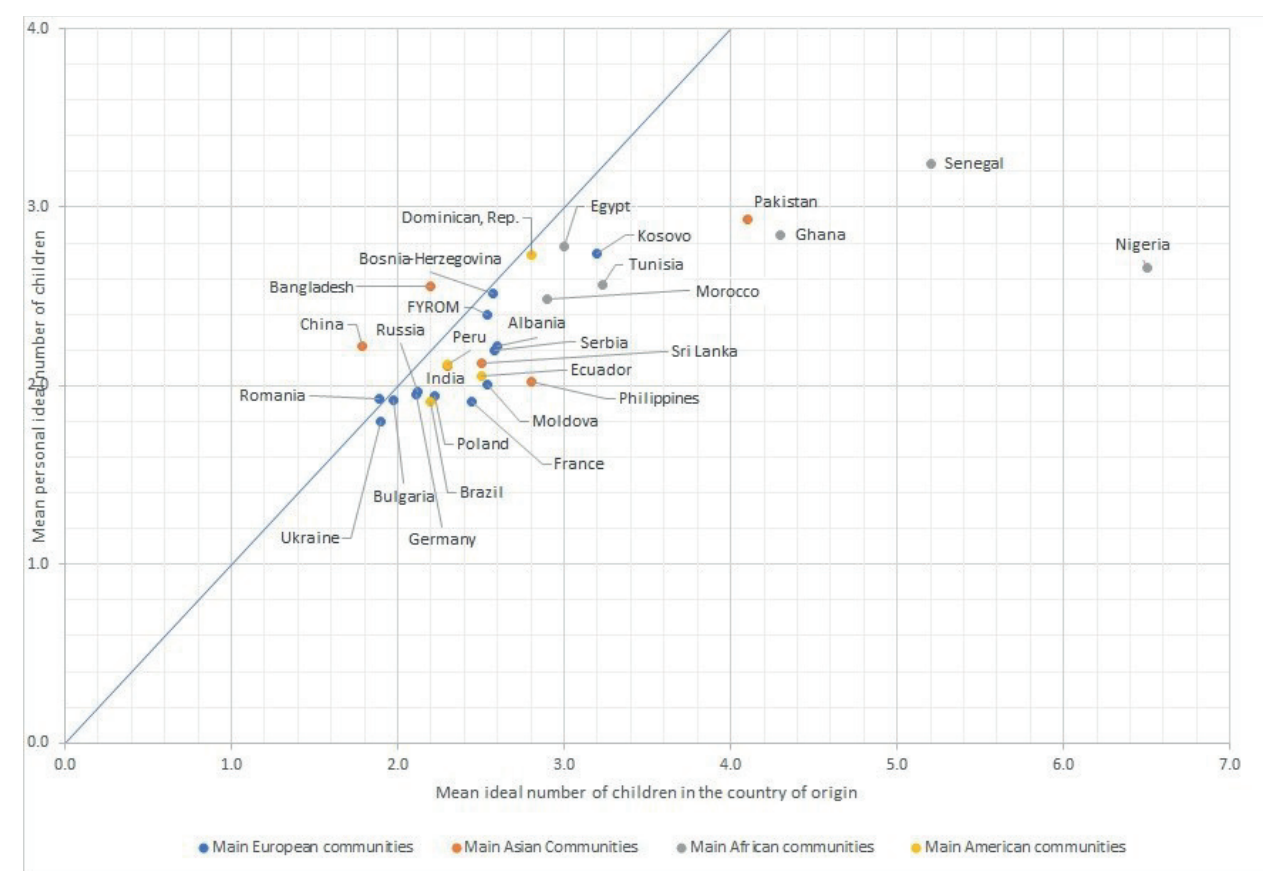

Source: Own calculation based on ISTAT survey "Social condition and integration of foreign citizens" 2011-12; Eurobarometer 2011; World Values Survey (1981-2008); DHS (1997-2011); MICS (2006-2016); PAPFAM (2001); RHS (2003).

children. Interestingly, women from China and Bangladesh have on average an ideal number of children slightly higher than that in their countries of birth.

\subsection{And what is the impact of country of birth, migration-related characteristics, female empowerment, and gender equity?}

Because we aim to identify the control variables with high predictive values in explaining differences with the norm in the origin country, we first run AIC and BIC tests. These two statistical tests follow a similar approach that allows us to see the predictive power of different covariates when the models are not nested. BIC is more susceptible to the degree of freedom, which is why the results are not always identical. Results are presented in Table A2 (in the Appendix) and show that the information with the largest predictive value is the parity; however, despite the large degree of freedom, the second-most important variables are the country of birth and gender equity.

For graphical reasons, we present the adjusted predictions at the means obtained from the multinomial logistic regression analyses of having the same, a low- 
er, or larger personal ideal number of children compared to the country of origin norm, or "Up to God" (UtG), or "I do not know" (IDK), by country of birth (Fig. 3), by age at arrival (Fig. 4), by duration of stay (Fig. 5), education (Fig. 6), labour market participation (Fig. 7) and by gender equity (Fig. 8). For each figure, the controls that were set to the population means are specified in the notes. The details about relative risk ratios obtained from the model for the independent variables are presented in Table A3 and A4 (in the Appendix).

Figure 3 shows the adjusted predictions of (dis)agreement between the personal ideal family size and the prevailing norm in the origin country. On the left side of the graph, we have the nationalities for which we observed larger proportions of women who have the same or larger ideal numbers of children norms than those prevalent in their origin country. These are all women from countries with ideal fertility norms of around 2 children. Women from Peru, Brazil, Germany, France, Bangladesh, and China are among the group showing non-negligible shares (between 21 and 30 percent) of women with an ideal number of children higher than their non-migrant co-nationals. Women from India, Bulgaria, Poland, Russia, Ukraine, Romania, other EU15, and other developed countries (ODC) for the most part share the same personal ideal family size of their country of birth (two children). Similar results were shown in the descriptive statistics (see Table 2).

Conversely, shares of women with a personal ideal number of children lower than their non-migrant co-nationals are found among natives of Ghana, Senegal, Nigeria, Tunisia, Morocco, other African countries (residual category), Albania, Moldova, Kosovo, Macedonia, Ecuador, Sri Lanka, the Philippines, and other Asian countries (residual category).

Those who are unsure about their ideal number of children are mostly women from the Philippines, Nigeria, other African countries (residual category), Macedonia (FYROM), EU15 and ODC citizens, other European countries (residual category), the Dominican Republic, and Ecuador. Finally, larger shares of women who do not quantify an ideal number of children by leaving it to "fate" or "God" (between 10 and 14 percent) are found among women born in Nigeria, Morocco, Senegal, other Latin American countries (residual category), Sri Lanka, and India. We therefore observe a significant effect of the country of origin even after controlling for other covariates (H1a and $\mathrm{H} 1 \mathrm{~b})$.

While agreement is more likely among women that move from a country characterised by the same average ideal fertility of Italy (two children), a deviation from the national norm towards a lower ideal number of children than the country of origin is more likely among women socialised in countries where large families are the norm. However, a non-negligible proportion of women who have a larger ideal than their country of origin (and also higher than the Italian norm) exists among women from countries characterised by the two-child norm.

In our second hypothesis, we assume that arriving as an adult might strengthen the preference for a personal ideal number similar to the origin country, compared to migrating as a child or young adult $(\mathrm{H} 2)$. Figure 4 shows that, according to the adjusted predictions at the means obtained from the multinomial logistic regression analyses, the largeest share of women with a personal ideal family size matching 
Fig. 3: Predicted probabilities of having the same, lower, or larger personal ideal number of children compared to the country of origin norm, or non-numeric responses, by country of origin

in percent

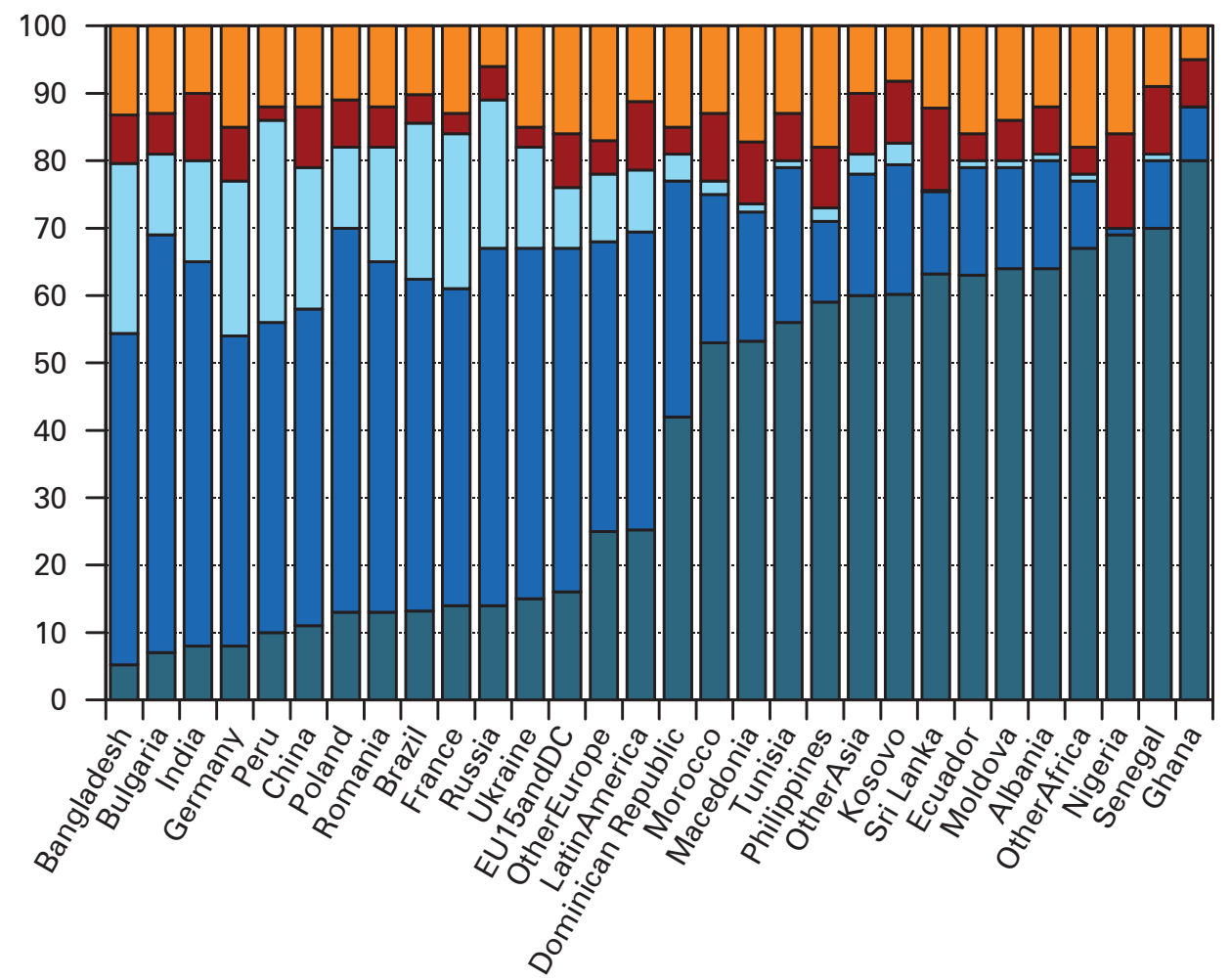

Personal ideal number of children
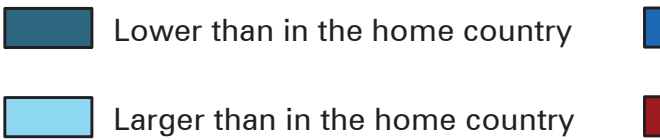

Larger than in the home country

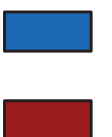

Equal than in the home country

Up to God

I don't know

Notes: We control for parity, marital status, age at the interview, age at interview squared, age at arrival, duration of stay, circular migration, education, gender equity, church attendance, labour market participation, and Italian proficiency. The controls are set to the population margins in destination countries, adjusted predictions at the means (APMs).

Source: Own calculation based on ISTAT survey "Social condition and integration of foreign citizens" 2011-12.

the country of origin is estimated to be among those who migrated at an older age (41 percent). This proportion decreases among those who came as a young adult (37 percent) and even more among those who arrived as children (28 percent). Among the latter group, the share with an ideal number of children lower than the 
Fig. 4: Predicted probabilities of having same, lower, or larger personal ideal number of children compared to the country of origin norm, or nonnumeric responses, by age at arrival

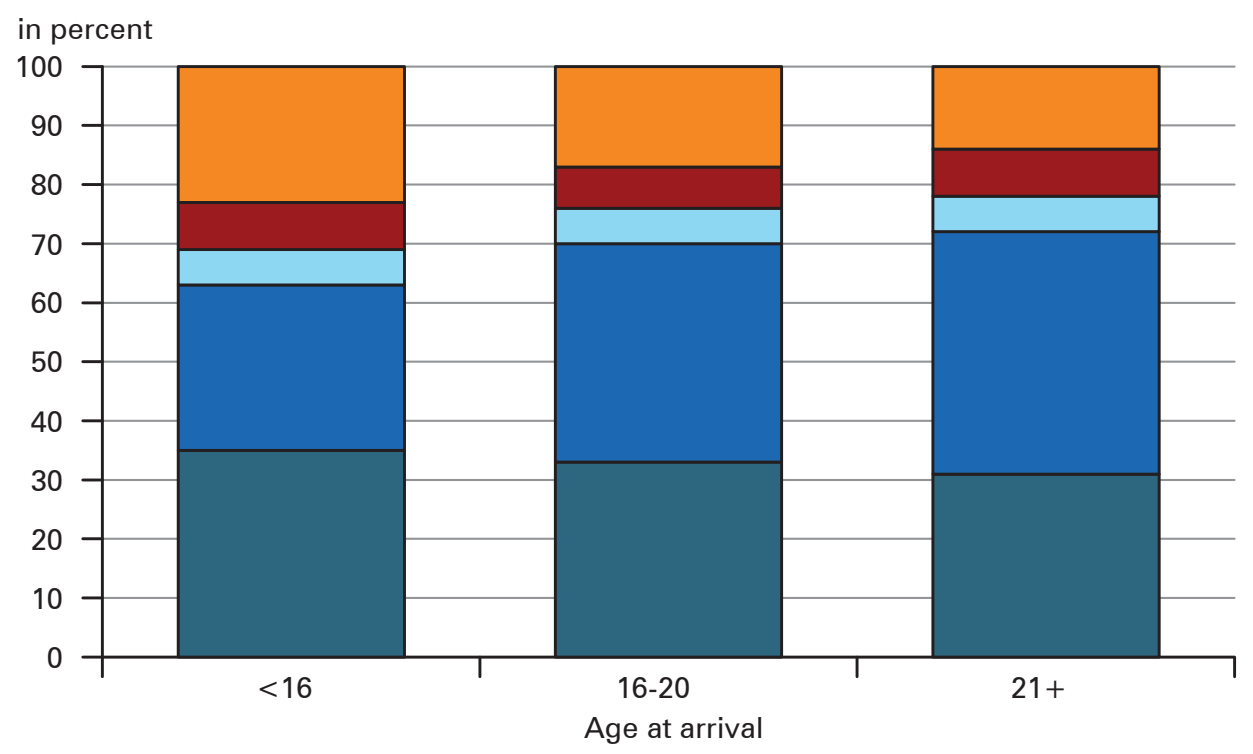

Personal ideal number of children

Notes: We control for parity, marital status, age at the interview, age at interview squared, country of birth, duration of stay, circular migration, education, gender ideology, church attendance, labour market participation, and Italian proficiency. The controls are set to the population margins in destination countries (APMs).

Source: Own calculation based on ISTAT survey "Social condition and integration of foreign citizens" 2011-12.

norm in the country of origin or who were unsure increases considerably. The effect of the time spent in the country of origin on the match of personal ideals with fertility ideals of the country of origin is, therefore, significant.

Although the effect of age at migration is significant, almost no differences in the adjusted predictions at the means exist among groups with different durations of stay in Italy (H3). Therefore, once other variables are controlled for, no sign of divergence from the origin norm due to the time spent in Italy emerges from the analysis. The proportions of women who have the same preferences as their birth-country peers were 37 percent for women who arrived less than 6 years ago, 38 percent for women who migrated between 6 and 10 years ago, and 40 percent for those who have spent more than 10 years in Italy (Fig. 5). 
Fig. 5: Predicted probabilities of having the same, lower, or larger personal ideal number of children compared to the country of origin norm, or non-numeric responses, by duration of stay

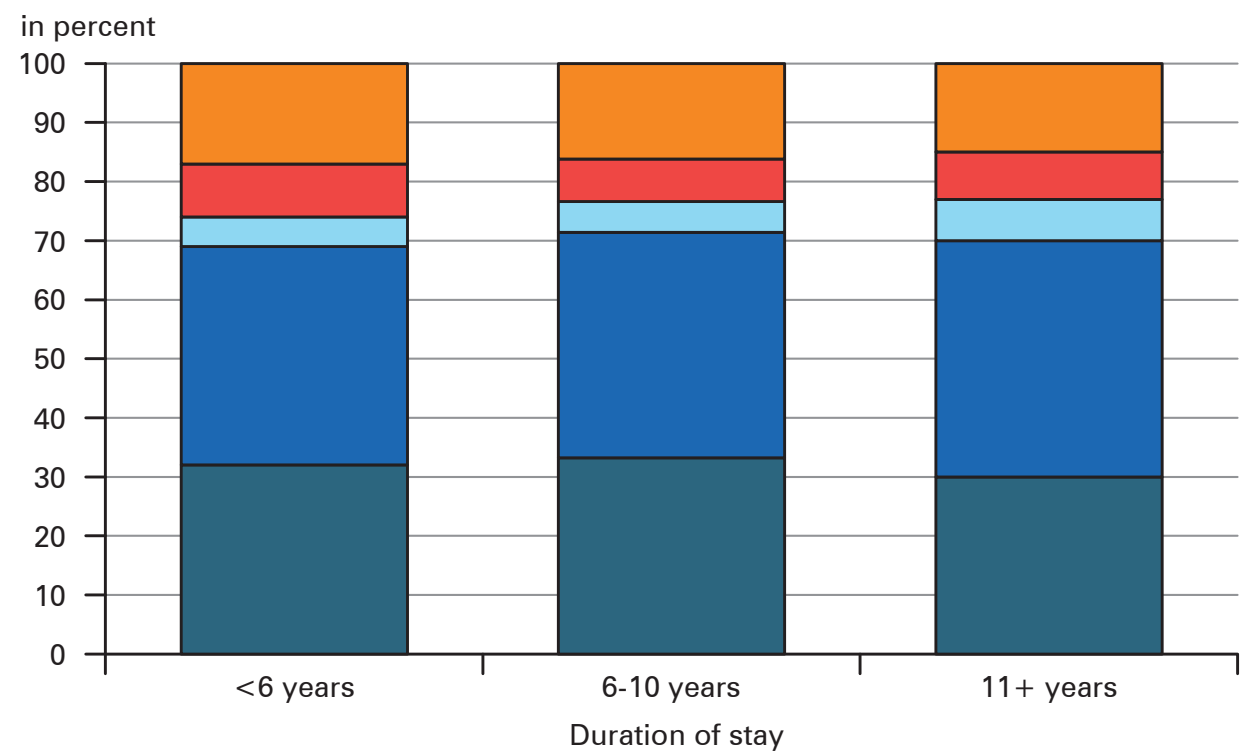

Personal ideal number of children

Lower than in the home country

Equal than in the home country

Larger than in the home country

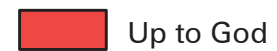

$\square$ I don't know

Notes: We control for parity, marital status, age at the interview, age at interview squared, age at arrival, country of birth, circular migration, education, gender ideology, church attendance, labour market participation, and Italian proficiency. The controls are set to the population margins in destination countries (APMs).

Source: Own calculation based on ISTAT survey "Social condition and integration of foreign citizens" 2011-12.

Finally, we hypothesised an effect of variables related to female empowerment (education and labour market participation) and gender equity on holding fertility preferences typical of the country of origin (H4). The main effect we observe is mostly a reduction of non-numeric responses. In particular, among women with high secondary school and post-secondary education, the proportion of "I don't know" decreases significantly compared to other women.

Labour market participation shows a similar effect of education: the share of non-numeric responses is higher among women not in the labour force. These women are also less likely to express a lower ideal than the country of origin.

The effect of variables related to empowerment (education and job participation) is similar to that observed regarding gender equity. Strong differences emerge in 
Fig. 6: Predicted probabilities of having the same, lower, or larger personal ideal number of children compared to the country of origin norm, or non-numeric responses, by education

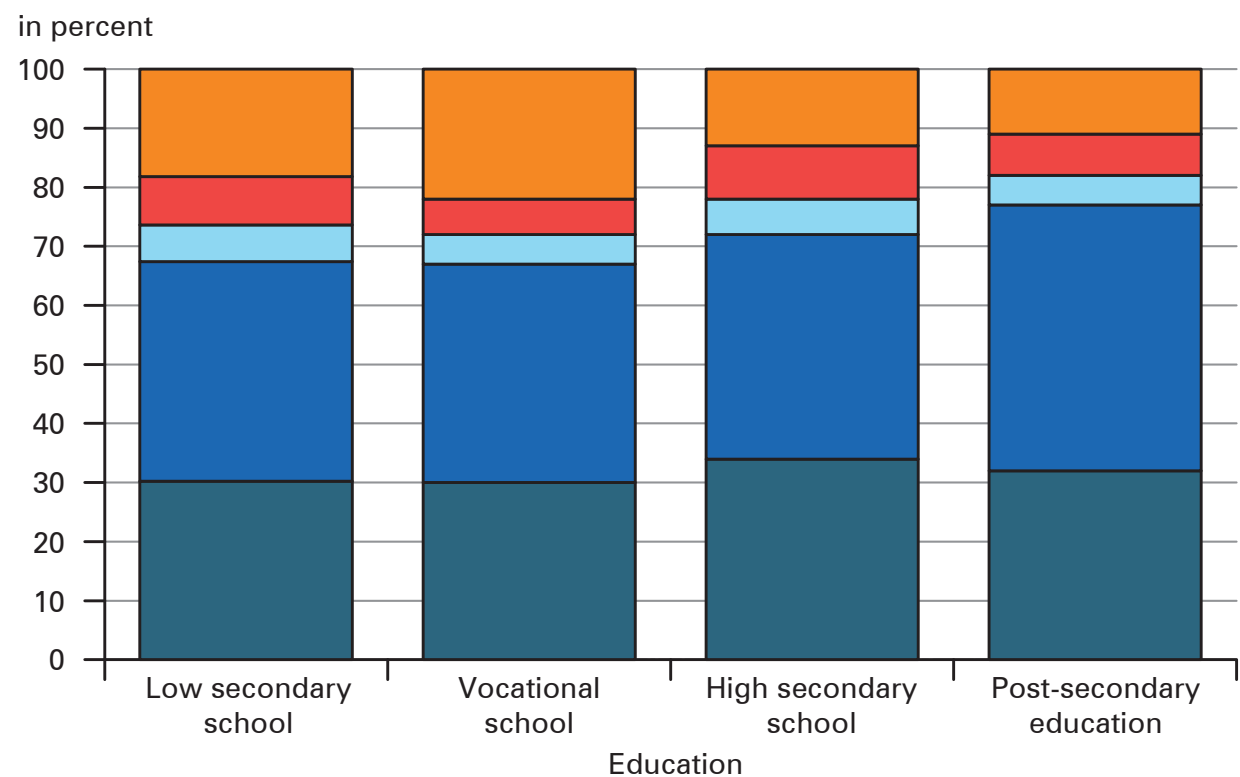

Personal ideal number of children

Notes: We control for parity, marital status, age at the interview, age at interview squared, country of birth, duration of stay, age at arrival, circular migration, gender ideology, church attendance, labour market participation, and Italian proficiency. The controls are set to the population margins in destination countries (APMs).

Source: Own calculation based on ISTAT survey "Social condition and integration of foreign citizens" 2011-12.

the proportions of adjusted predictions at the means by support for gender equity (Fig. 8). The effect of support for gender equity is most evident regarding a reduction of the share of women who are unsure about their ideal family size, or who leave fertility to fate or God, thereby indicating a preference for having as many children as possible. Data show that women who support gender equity also have a clearer idea of their fertility ideals, showing that they have internalised the idea that fertility can be legitimately controlled and personal ideals matter $(5$ percent vs. 13 percent UtG and 13 percent vs. 20 percent IDK, respectively, for women with equal gender equity vs. no equity).

Our main interest is to compare migrants' ideal number of children with the typical ideal number of children of people remaining in the country of origin - by 
Fig. 7: Predicted probabilities of having the same, lower, or larger personal ideal number of children compared to the country of origin norm, or non-numeric responses, by labour market participation

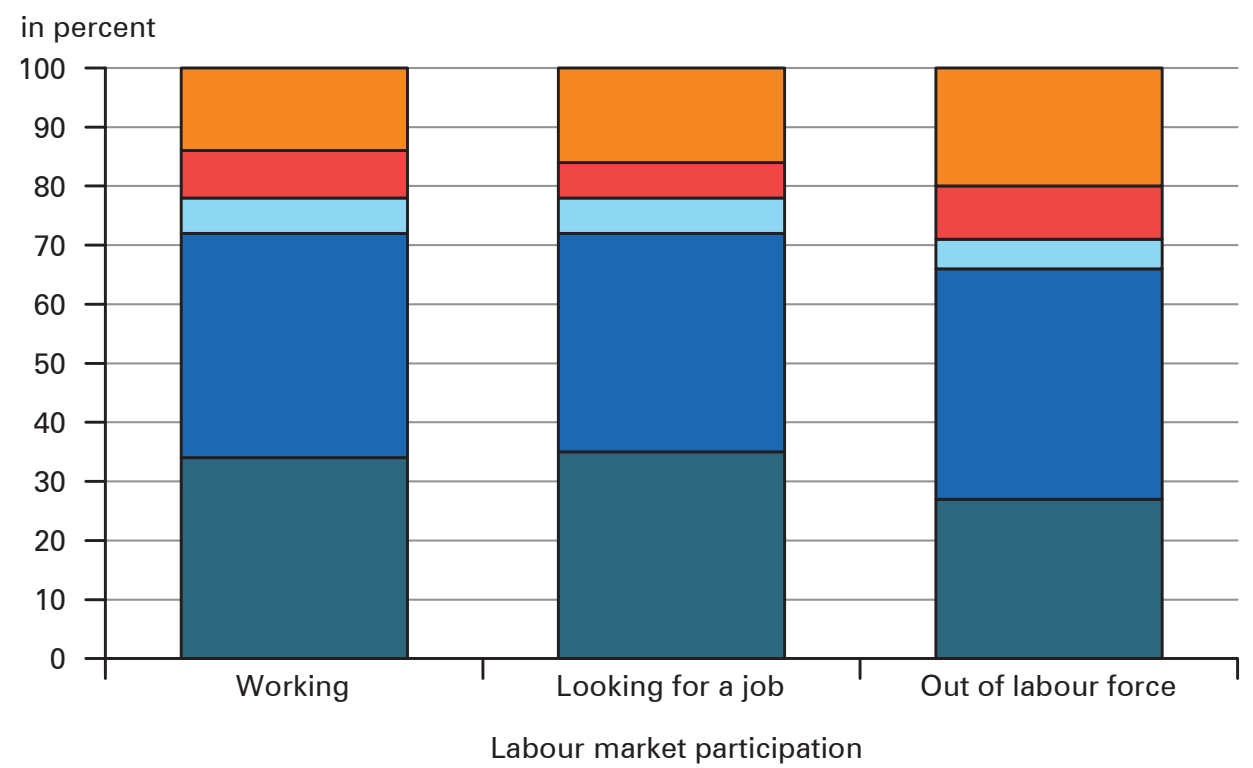

Personal ideal number of children

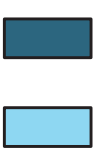

Lower than in the country of origin

Same of the country of origin

Larger than in the country of origin

Up to God

I don't know

Notes: We control for parity, marital status, age at the interview, age at interview squared, country of birth, duration of stay, age at arrival, circular migration, gender ideology, church attendance, education, and Italian proficiency. The controls are set to the population margins in destination countries (APMs).

Source: Own calculation based on ISTAT survey "Social condition and integration of foreign citizens" 2011-12.

country of birth, age at arrival, duration of stay, woman empowerment and gender ideology. Relative Risk Ratios (RRR) for individual demographic and socioeconomic characteristics of immigrant women in Italy are shown and commented in Table A3 in the appendix. 
Fig. 8: $\quad$ Predicted probabilities of having the same, lower, or larger personal ideal number of children compared to the country of origin norm, or non-numeric responses, by support for gender equity

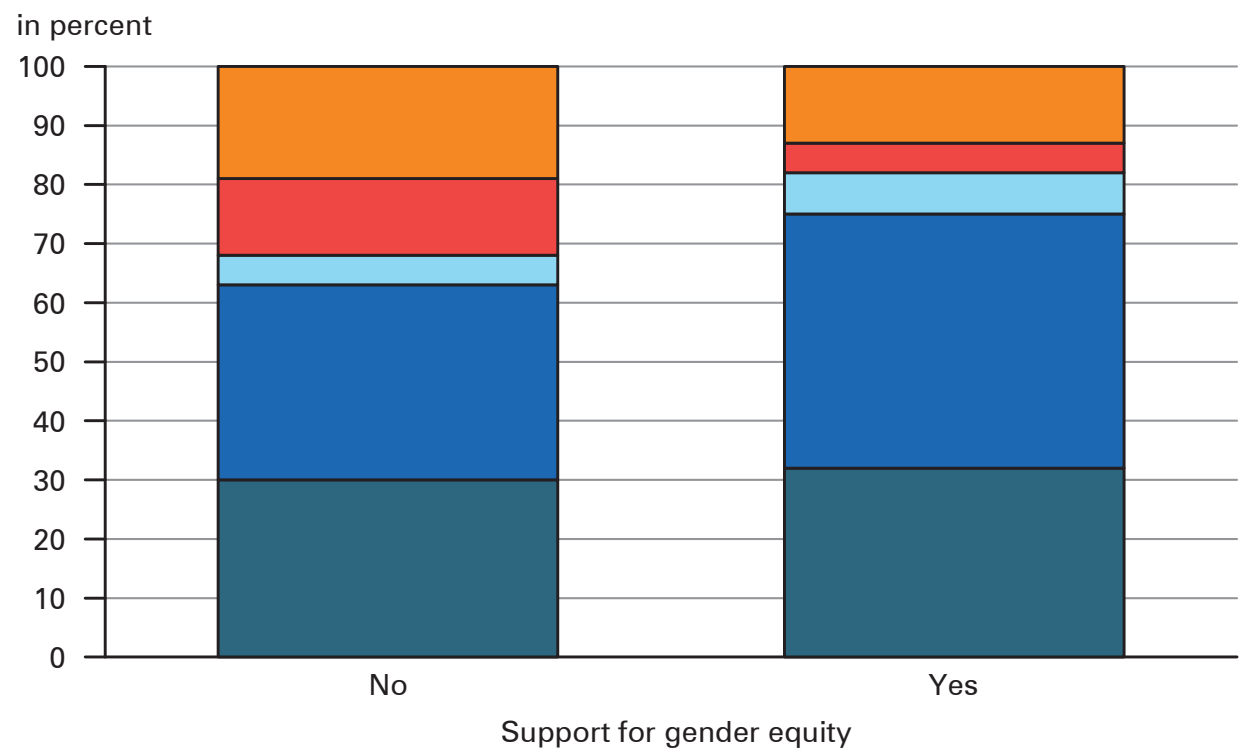

Personal ideal number of children

Notes: We control for parity, marital status, age at interview, age at interview squared, age at arrival, duration of stay, circular migration, education, country of birth, church attendance, labour market participation, and Italian proficiency. The controls are set to the population margins in destination countries (APMs).

Source: Own calculation based on ISTAT survey "Social condition and integration of foreign citizens" 2011-12.

\section{$5 \quad$ Conclusion and discussion}

The study of the personal ideal family size of immigrants has a promising and so far underdeveloped potential to disclose the relationship between migration and fertility. In this study, we compared the personal ideal family size of migrant women in Italy to the prevailing norm of stayers in their respective countries of origin and analyse determinants of agreement and disagreement between these norms.

Despite filling an unexplored gap in the current literature related to the migration-fertility nexus, our study has a limitation that should be taken into consideration when reading our results. The lack of information about personal fertility ideals before migration prevents us from explicitly testing two fundamental hypotheses 
about migrant fertility - namely, the selection and the adaptation hypotheses. While analysing (dis)agreement with the country of origin norm, we cannot infer whether migrants shared that norm before migration. When analysing women who show a different ideal compared to their country of origin average, it is unknown whether they held such ideals even before migration (i.e. self-selection; the selection hypothesis) or if living in Italy changed their ideals (adaptation hypothesis). We cannot even a priori exclude, despite the hypothesis being highly unlikely, that a minority of women might have "reactivated" their "ethnicity" and adopted the country ideal due to phenomena of reactive ethnicity (Diehl/Schnel/ 2006), despite having a different fertility ideal before migration.

Bearing this limitation in mind, our paper shows that among migrants residing in Italy, the majority would like to have two children. One woman out of three in the sample shares the norm of their country of origin, and another one in three has a lower ideal than the country of origin average. Women who have a higher ideal number of children than their non-migrant peers represent only 11 percent of the sample. The agreement between personal ideal family size at the moment of the survey and the average country norm is associated with women's specific country of origin background ( $\mathrm{H} 1 \mathrm{a})$, even when we control for socio-economic and demographic factors $(\mathrm{H} 1 \mathrm{~b})$. Our results confirm that the country of birth has a large predictive value in explaining the occurrence of agreement with the country of origin norm and the possible direction of shift in the ideal family size. Agreement with the national fertility ideal is typical of women from countries where two children are the fertility norm. A deviation towards a lower ideal number of children than in the country of origin is more likely among women who grew up in countries where large families are idealised. However, women with larger ideal families than those in the country of origin are also observed. The country of origin background also has an overall effect on the prevalence of non-numeric responses. The share of women unsure or expressing a preference for a maximum number of children, leaving its determination to fate or God, varies significantly by country of origin. Relations and social networks between members of the same origin community in the destination country might build and reinforce fertility norms shared within a community, explaining the role of country of origin.

Even more interestingly, our results show that the correspondence between the personal ideal and the ideal of the country of origin is mostly related to socialisation in the country of origin: arriving as an adult is related to the overall agreement with the country of origin ideal $(\mathrm{H} 2)$. Few differences exist between women who migrated at 21 and over and between age 16 and 20. This finding suggests that, in the likely event that women whose ideals match their average country norm had that same ideal even before migration, ideals are imprinted during the early years of a woman's life and retained during adulthood according to the socialisation hypothesis. Moreover, the 1.5 generation has a higher share of "I don't know" answers. Despite model's controls, this might still be affected by a younger age at the interview among these women, since fertility ideals of adolescents and young adults tend to be more uncertain compared to those of older women (Berrington/Pattaro 2014; Kraus/Castro-Martín 2017). 
Another crucial result underlined by our study is that time since migration has no significant impact on the match between personal ideals and the average family ideals of the country of origin, rejecting the hypothesis that a longer time spent in the country of migration might cause a shift away from the ideals imprinted during childhood and adolescence (H3). In other words, we cannot say whether women whose ideal stated in the survey does not match their country average formed that ideal before migration (selection) or changed it because of migration. However, we can say that if migration drove the change, the effect is not time-dependent. This result is entirely in line with the literature affirming that personal ideal family size is more of an assimilated social norm than a personal preference, and for this reason does not change over time (Thomson 2015).

Our study further confirms the association between support for gender equity and empowerment and fertility ideals. The effect observed is most evident in the occurrence of non-numeric responses (family size is "up to God" or "I don't know"). Higher support for gender equity, education, and participation in the job market results in a lower proportion of non-numeric responses. Support for gender equity and empowerment is related to a reduction in uncertainty, implying that more empowered women who support gender equity are also more likely to consider fertility as a sphere in which they can have an opinion and express ideals.

Finally, our results raise the question of whether a possible replication of this study in a more gender-equal country (e.g. those in Northern Europe), compared to the rather traditional Italy, would result in an even stronger effect of gender beliefs on fertility ideals.

\section{Acknowledgements}

This research was supported by the Linnaeus Center on Social Policy and Family Dynamics in Europe - Spade (grant registration number 349-2007-8701); the Swedish Research Council for Health, Working life and Welfare (FORTE), grant number 2016-07105 and 2018-00310 and the Swedish Research Council (Vetenskapsrådet), grant number 2017-01021.

We would like to thank the reviewers and the editors for their thoughtful comments and suggestions.

\section{References}

Ager, Alstair; Strang, Alison 2008: Understanding Integration: A Conceptual Framework. In: Journal of Refugee Studies 21,2: 166-191 [doi: 10.1093/jrs/fen016].

Alba, Richard; Nee, Victor 2003: Remaking the American Mainstream: Assimilation and Contemporary Immigration. Cambridge: Harvard University Press.

Algan, Yann et al. (Eds.) 2012: Cultural Integration of Immigrants in Europe, Studies of Policy Reform. Oxford University Press, UK. 
Andersson, Gunnar 2004: Childbearing after Migration: Fertility Patterns of Foreignborn Women in Sweden. In: International Migration Review 38,2: 747-774 [doi: 10.1111/ j.1747-7379.2004.tb00216.x].

Arpino, Bruno; Esping-Andersen, Gøsta; Pessin, Lea 2015: How Do Changes in Gender Role Attitudes Towards Female Employment Influence Fertility? A Macro-Level Analysis. In: European Sociological Review 31,3: 370-382 [doi: 10.1093/esr/jcv002].

Baykara-Krumme, Helen; Milewski, Nadja 2017: Fertility Patterns among Turkish Women in Turkey and Abroad: The Effects of International Mobility, Migrant Generation, and Family Background. In: European Journal of Population 33,3: 409-436 [doi: 10.1007/ s10680-017-9413-9].

Berghammer, Caroline 2012: Church Attendance and Childbearing: Evidence from a Dutch Panel Study, 1987-2005. In: Population Studies 66,2: 197-212 [doi: 10.1080/00324728.2012.655304].

Berrington, Ann; Pattaro, Serena 2014: Educational differences in fertility desires, intentions and behaviour: A life course perspective. In: Advances Life Course Research 21: 10-27 [doi: 10.1016/j.alcr.2013.12.003].

Billari, Francesco C.; Philipov, Dimiter; Testa, Maria Rita 2009: Attitudes, Norms and Perceived Behavioural Control: Explaining Fertility Intentions in Bulgaria. In: European Journal of Population 25: 439-466 [doi: 10.1007/s10680-009-9187-9].

Blake, Judith 1966: Ideal Family Size among White Americans: A Quarter of a Century's Evidence. In: Demography 3,1: 154-173.

Blau, Francine D. 2015: Immigrants and Gender Roles: Assimilation Vs. Culture. In: IZA Journal of Migration 4,23: 1-21 [doi: 10.1186/s40176-015-0048-5].

Bolzendahl, Catherine l.; Myers, Daniel. J. 2004: Feminist Attitudes and Support for Gender Equality: Opinion Change in Women and Men, 1974-1998. In: Social Forces 83,2: 759-789 [doi: 10.1353/sof.2005.0005].

Bulatao, Rodolfo A. et al. 1983: Determinants of Fertility in Developing Countries: A Summary of Knowledge. Washington D.C.: National Academy Press.

De Valk, Helga A.G. 2013: Intergenerational Discrepancies in Fertility Preferences among Immigrant and Dutch families. In: The History of the Family 18,2: 209-225 [doi: 10.1080/1081602X.2013.826591]

Diehl, Claudia; Schnell, Rainer 2006: "Reactive Ethnicity" or "Assimilation"? Statements, Arguments, and First Empirical Evidence for Labor Migrants in Germany. In: International Migration Review 40,4: 786-816 [doi: 10.1111/j.1747-7379.2006.00044.x].

Doepke, Matthias; Tertilt, Michele 2018: Women's Empowerment, the Gender Gap in Desired Fertility, and Fertility Outcomes in Developing Countries. In: IZA Discussion Paper Series. Bonn: IZA Institute of Labor Economics [https://ssrn.com/abstract $=3111136,08.11 .2018]$.

Esping-Andersen, Gøsta; Billari, Francesco C. 2015: Re-theorizing Family Demographics. In: Population and development review 41,1: 1-31 [doi: 10.1111/j.17284457.2015.00024.x].

Eurostat 2018: Online Database [http://ec.europa.eu/eurostat/data/database, 08.11.2018].

Fan, Pi-Ling; Marini, Margaret Mooney 2000: Influences on Gender-role Attitudes During the Transition to Adulthood. In: Social Science Research 29,2: 258-283 [doi: 10.1006/ ssre.1999.0669]. 
Fargues, Philippe 2007: The Demographic Benefit of International Migration: A Hypothesis and its Application to Middle Eastern and North African Countries. In: World Bank Policy Research Working Paper 4050. Washington, DC: The World Bank [doi: 10.1596/1813-9450-4050].

Finer, Lawrence B.; Zolna, Mia R. 2016: Declines in Unintended Pregnancy in the United States, 2008-2011. In: N Engl Med 374: 843-852 [doi: 10.1056/NEJMsa1506575].

Frejka, Tomas; Westoff, Charles F. 2008: Religion, Religiousness and Fertility in the US and in Europe. In: European Journal of Population 24,1: 5-31 [doi: 10.1007/s10680-0079121-y].

Frye, Margaret; Bachan, Lauren 2017: The Demography of Words: The Global Decline in Non-numeric Fertility Preferences, 1993-2011. In: Population Studies 71,2 [doi: 10.1080/00324728.2017.1304565].

Gàlvez, Alyshia 2011: Patient Citizens, Immigrant Mothers: Mexican Women, Public Prenatal Care, and the Birth-weight Paradox. New Brunswick/New Jersey/London: Rutgers University Press [doi: 10.1111/j.1935-4940.2012.01258.x].

Genereux, Anne 2007: A Review of Migration and Fertility Theory through the Lens of African Immigrant Fertility in France. MPIDR Working Paper WP 2007-008. Rostock: Max Planck Institute for Demographic Research.

Gordon, Milton 1964: Assimilation in American Life. New York: Oxford University Press.

Hayford, Sarah R.; Morgan, Philip S. 2008: Religiosity and Fertility in the United States: The Role of Fertility Intentions. In: Soc Forces 86,3: 1163-1188 [doi: 10.1353/sof.0.0000].

Hayford, Sarah R.; Agadjanian, Victor 2011: Uncertain Future, Non-numeric Preferences, and the Fertility Transition: A Case Study of Rural Mozambique. In: African Population Studies 25,2: 419-439 [doi: 10.11564/25-2-239].

Holland, Jennifer A.; de Valk, Helga 2013: Ideal Ages for Family Formation among Immigrants in Europe. In: Advances in Life Course Research 18;4: 257-269 [doi: 10.1016/j. alcr.2013.08.002].

lacovou, Maria; Tavares, Lara Patrício 2011: Yearning, Learning, and Conceding: Reasons Men and Women Change their Childbearing Intentions. In: Population and Development Review 37,1: 89-123 [doi: 10.1111/j.1728-4457.2011.00391.x].

Kearns, Ade; Whitley, Elise 2015: Getting There? The Effects of Functional Factors, Time and Place on the Social Integration of Migrants. In: Journal of Ethnic and Migration Studies 41,13: 2105-2129 [doi: 10.1080/1369183X.2015.1030374].

King, Russe/ 2000: Southern Europe in the Changing Global Map of Migration. In: King, Russel; Lazaridis, Gabriella; Tsardanidis, Charalambos (Eds.): Eldorado or Fortress? Migration in Southern Europe. London: Palgrave Macmillan [doi: 10.1057/9780333982525_1].

Kraus, Elizabeth K.; Castro-Martin, Teresa 2017: Does Migrant Background Matter for Adolescents' Fertility Preferences? The Latin American 1.5 Generation in Spain. In: European Journal of Population 34, 3: 277-312 [doi: 10.1007/s10680-017-9427-3].

Kuhnt, Anne-Kristin; Kreyenfeld, Michaela; Trappe, Heike 2017: Fertility Ideals of Women and Men Across the Life Course. In: Kreyenfeld, Michaela; Konietzka, Dirk (Eds.): Childlessness in Europe: Contexts, Causes, and Consequences. In: Demographic Research Monographs (A series of the Max Planck Institute for Demographic Research). Springer, Cham [doi: 10.1007/978-3-319-44667-7_11].

Kulu, Hill 2005: Migration and Fertility: Competing Hypotheses Re-examined. In: European Journal of Population 21,1: 51-87 [doi: 10.1007/s10680-005-3581-8]. 
Kulu, Hill et al. 2017: Fertility by Birth Order among the Descendants of Immigrants in Selected European Countries. In: Population and Development Review 43,1: 31-60 [doi: 10.1111/padr.12037].

Lesthaeghe, Ron (Ed.) 2002: Meaning and Choice: Value Orientations and Life Course Decisions. The Hague: NIDI/CBGS.

Lieberson, Stanley; Waters, Mary C. 1988: From Many Strands: Ethnic and Racial Groups in Contemporary America. New York: Russell Sage Foundation.

Liefbroer, Aart C.; Billari, Francesco C. 2010: Bringing Norms Back In: A Theoretical and Empirical Discussion of Their Importance for Understanding Demographic Behaviour. In: Population Space Place 16,4: 287-305 [doi: 10.1002/psp.552].

Martin, Steven P. 2004: Delayed Marriage and Childbearing: Implications and Measurement of Diverging Trends in Family Timing. In: Neckerman, Kathryn (Ed.): Social Inequality. New York: Russell Sage: 79-118.

Mayer, Jochen; Riphahn, Regina T. 2000: Fertility Assimilation of Immigrants: Evidence from Count Data Models. In: Journal of Population Economics 13,2: 241-261.

McDonald, Peter 2006: Low Fertility and the State: The Efficacy of Policy. In: Population and Development Review 32,3: 485-510 [doi: 10.1111/j.1728-4457.2006.00134.x].

McDonald, Peter 2013: Societal Foundations for Explaining Low Fertility: Gender Equity. In: Demographic Research 28: 981-994 [doi: 10.4054/DemRes.2013.28.34].

Mencarini, Letizia; Tanturri, Maria Letizia 2004: Time use, family role-set and childbearing among Italian working women. In: Genus 60,1: 111-137.

Milewski, Nadja 2010: Immigrant Fertility in West Germany: Is There a Socialization Effect in Transitions to Second and Third Births? In: European Journal of Population/ Revue européenne de Démographie 26,3: 297-323 [doi: 10.1007/s10680-010-9211-0].

Mills, Melinda 2010: Gender Roles, Gender (In)equality and Fertility: An Empirical Test of Five Gender Equity Indices. In: Canadian Studies in Population 37,3-4: 445-474 [doi: 10.25336/P61310].

Mills, Melinda et al. 2008: Gender Equity and Fertility Intentions in Italy and the Netherlands. In: Demographic Research 18,1: 1-26 [doi: 10.4054/DemRes.2008.18.1].

Mussino, Eleonora; Strozza, Salvatore 2012a: The Fertility of Immigrants after Arrival: The Italian Case. In: Demographic Research 26,4: 99-130 [doi: 10.4054/DemRes.2012.26.4].

Mussino, Eleonora; Strozza, Salvatore 2012b: Does Citizenship Still Matter? Second Birth Risks of Migrants from Albania, Morocco, and Romania in Italy. In: European Journal of Population/Revue européenne de Démographie 28,3: 269-302 [doi: 10.1007/ s10680-012-9261-6].

Nauck, Bernhard 1987: Individuelle und kontextuelle Faktoren der Kinderzahl in türkischen Migrantenfamilien. In: Zeitschrift für Bevölkerungswissenschaft 13,3: 319-344.

Neyer, Gerda; Lappegård, Trude; Vignoli, Daniele 2013: Gender Equality and Fertility: Which Equality Matters? In: European Journal of Population 29: 245 [doi: 10.1007/ s10680-013-9292-7].

OECD 2016: Ideal and Actual Number of Children. Online resource [https://www.oecd. org/els/family/SF_2_2-Ideal-actual-number-children.pdf, February 2018].

Olaleye, David 1993: Ideal Family Size: A Comparative Study of Numerical and Nonnumerical Fertility Desires of Women in Two sub-Saharan African Countries. In: DHS Woking Paper 7. Calverton, MD: Macro International. 
Ortensi, Livia E. 2015: Engendering the Fertility-migration Nexus: The Role of Women's Migratory Patterns in the Analysis of Fertility After Migration. In: Demographic Research 32: 1435-1468 [doi: 10.4054/DemRes.2015.32.53].

Penn, Roger; Lambert, Paul 2002: Attitudes Towards Ideal Family Size of Different Ethnic/nationality Groups in Great Britain, France and Germany. In: Population Trends Summer 108: 49-58.

Peri-Rotem, Nitzan 2016: Religion and Fertility in Western Europe: Trends Across Cohorts in Britain, France and the Netherlands. In: European Journal of Population 32,2: 231-265 [doi: 10.1007/s10680-015-9371-z].

Philipov, Dimiter; Bernardi, Laura 2011: Reproductive Decisions: Concepts and Measurement in Austria, Germany and Switzerland. In: Comparative Population Studies 36,2-3: 495-530 [doi: 10.4232/10.CPoS-2011-14en].

Quesnel-Vallée, Amélie; Morgan, S. Philip 2003: Missing the Target? Correspondence of Fertility Intentions and Behavior in the U.S.. In: Population Research and Policy 22,5-6: 497-525 [doi: 10.1023/B:POPU.0000021074.33415.c1].

Rindfuss, Ronald R. 1976: Fertility and Migration: The Case of Puerto Rico. In: International Migration Review 10,2: 191-203.

Sedgh, Gilda; Singh, Susheela; Hussain, Rubina 2014: Intended and Unintended Pregnancies Worldwide in 2012 and Recent Trends. In: Studies in Family Planning 45,3: 301-314 [doi: 10.1111/j.1728-4465.2014.00393.x].

Searle, Shayle Robert; Speed, F.M.; Milliken, George A. 1980: Population Marginal Means in the Linear Model: An Alternative to Least Squares Means. In: The American Statistician 34,4: 216-221 [doi: 10.2307/2684063].

Sobotka, Tomáš 2008: The Rising Importance of Migrants for Childbearing in Europe. In: Demographic Research 19,9: 225-248 [doi: 10.4054/DemRes.2008.19.9].

Sobotka, Tomáš; Beaujouan, Éva 2014: Two Is Best? The Persistence of a Two-Child Family Ideal in Europe. In: Population and Development Review 40,3: 391-419 [doi: 10.1111/j.1728-4457.2014.00691.x].

Statham, Paul; Tillie, Jean 2016: Muslims in Their European Societies of Settlement: A Comparative Agenda for Empirical Research on Socio-cultural Integration Across Countries and Groups: In: Journal of Ethnic and Migration Studies 42,2: 177-196 [doi: 10.1080/1369183X.2015.1127637].

Testa, Maria Rita 2012: Family Sizes in Europe: Evidence from the 2011 Eurobarometer Survey. European Demographic Research Papers. Vienna: Institute of Demography.

Testa, Maria Rita; Grilli, Leonardo 2006: The Influence of Childbearing Regional Contexts on Ideal Family Size in Europe. In: Population 61: 99-127 [doi: 10.3917/pope.601.0099].

Tazi-Preve, Irene M.; Bichlbauer, Dieter; Goujon, Anne 2004: Gender Trouble and Its Impact on Fertility Intentions. In: Yearbook of Population Research in Finland 40: 5-24.

Thomson, Elizabeth 2015: Family Size Preferences. In: Wright, James D. (Ed.): International Encyclopedia of the Social and Behavioral Sciences. Second Edition. Oxford: Elsevier Ltd.

Toulemon, Laurent 2001: Why Fertility is Not So Low in France: Paper presented at the IUSSP - International Union for Scientific Study of Population - Seminar on International Perspectives on Low Fertility: Trends, Theories and Policies: Tokyo, 21-23 March 2001.

Trent, Roger B. 1980: Evidence Bearing on the Construct Validity of "Ideal Family Size". In: Population and Environment 3,3-4: 309-327 [doi: 10.1007/BF01255345]. 
Unger, Jennifer B.; Molina, Gregory B. 1997: Desired Family Size and Son Preference Among Hispanic Women of Low Socioeconomic Status. In: Family Planning Perspectives 29,6: 284-287 [doi: 10.1363/2928497].

Upadhyay, Ushma D.; Karasek, Deborah 2012: Women's Empowerment and Ideal Family Size: An Examination of DHS Empowerment Measures in Sub-Saharan Africa. In: International Perspectives on Sexual and Reproductive Health 38,2: 78-89 [doi: 10.1363/3807812].

Upadhyay, Ushma D. et al. 2014: Women's Empowerment and Fertility: A Review of the Literature. In: Social Science \& Medicine 115: 111-120 [doi: 10.1016/j.socscimed.2014.06.014].

Van De Kaa, Dirk J. 2001: Postmodern Fertility Preferences: From Changing Value Orientation to New Behaviour. In: Population and Development Review 27, Supplement: Global Fertility Transition: 290-331.

Van de Walle, Etienne 1992: Fertility Transition, Conscious Choice, and Numeracy. In: Demography 29,4: 487-502.

Westoff, Charles F.; Potvin, Raymond H. 1967: College Women and Fertility Values. Princeton: Princeton University Press [doi: 10.1515/9781400876051].

Weston, Ruth; Qu, Lixia; Parker, Robyn 2005: It's Not for Lack of Wanting Kids... A Report on the Fertility Decision Making Project. Research Report No. 11. Melbourne: Australian Institute of Family Studies.

White, Michael J.; Moreno, Lorenzo; Guo, Shenyang 1995: The Interrelation of Fertility and Geographic Mobility in Peru: A Hazards Model Analysis. In: International Migration Review 29,2: 492-514 [doi: 10.2307/2546791].

Williams, Richard 2012: Using the Margins Command to Estimate and Interpret Adjusted Predictions and Marginal Effects. In: The Stata Journal 12,2: 308-331.

Woldemicael, Gebremariam 2009: Women's Autonomy and Reproductive Preferences in Eritrea. In: Journal of Biosocial Science 41;2: 161-181 [doi: 10.1017/ S0021932008003040].

Zuo, Jipingand; Tang, Shengming 2000: Breadwinner Status and Gender Ideologies of Men and Women Regarding Family Roles. In: Sociological Perspectives 43,1: 29-43 [doi: 10.2307/1389781].

Eleonora Mussino. Stockholm University. Stockholm, Sweden.

E-mail: eleonora.mussino@sociology.su.se,

https://www.su.se/english/profiles/emuss-1.189704

Livia Elisa Ortensi ( $₫)$. University of Milan, Bicocca. Milan, Italy.

E-mail: livia.ortensi1@unimib.it, URL: https://www.unimib.it/livia-elisa-ortensi

Authors appear in alphabetical order. 


\section{Appendix}

Tab. A1: Sample description in absolute values and percentages $(N=7,307)$

\begin{tabular}{|c|c|c|c|c|c|}
\hline & $\begin{array}{c}\text { Absolute } \\
\text { Values }\end{array}$ & $\%$ & & $\begin{array}{l}\text { Absolute } \\
\text { Values }\end{array}$ & $\%$ \\
\hline Country of Birth: & \multicolumn{4}{|c|}{ Previous children: } & \\
\hline Albania (Ref.) & 673 & 9.2 & 0 (Ref.) & 2520 & 34.5 \\
\hline EU15 and ODCs & 204 & 2.8 & 1 & 1857 & 25.4 \\
\hline Other Europe & 294 & 4.0 & 2 & 1933 & 26.5 \\
\hline Other Africa & 299 & 4.1 & 3 & 996 & 13.6 \\
\hline Other Latin America & 127 & 1.7 & \multicolumn{3}{|l|}{ Age at arrival: } \\
\hline Other Asia & 201 & 2.8 & $<16$ years (Ref.) & 864 & 11.8 \\
\hline Bulgaria & 85 & 1.2 & $16-20$ years & 1229 & 16.8 \\
\hline France & 79 & 1.1 & $21+$ years & 5214 & 71.4 \\
\hline Germany & 58 & 0.8 & \multicolumn{3}{|l|}{ Duration of stay: } \\
\hline Poland & 263 & 3.6 & $<6$ years (Ref.) & 2135 & 29.2 \\
\hline Romania & 1808 & 24.7 & $6-10$ years & 2796 & 38.3 \\
\hline Ukraine & 384 & 5.3 & $11+$ years & 2376 & 32.5 \\
\hline Russia & 85 & 1.2 & \multicolumn{3}{|l|}{ Gender equity: } \\
\hline Macedonia (FYROM) & 117 & 1.6 & No (Ref.) & 3548 & 48.6 \\
\hline Moldova & 269 & 3.7 & Yes & 3759 & 51.4 \\
\hline Kosovo & 75 & 1.0 & \multicolumn{3}{|l|}{ Marital status: } \\
\hline Bangladesh & 84 & 1.1 & Never been married (Ref.) & 2304 & 31.5 \\
\hline Sri Lanka & 105 & 1.4 & Married & 3999 & 54.7 \\
\hline China & 267 & 3.7 & \multicolumn{3}{|l|}{ Separated/widowed/ } \\
\hline Philippines & 187 & 2.6 & divorced & 1003 & 13.7 \\
\hline India & 156 & 2.1 & Age interview & \multicolumn{2}{|l|}{33.7} \\
\hline Ghana & 57 & 0.8 & \multicolumn{3}{|l|}{ Circular migration: } \\
\hline Morocco & 618 & 8.5 & stable (Ref.) & 7108 & 97.3 \\
\hline Nigeria & 86 & 1.2 & Circular & 199 & 2.7 \\
\hline Senegal & 67 & 0.9 & \multicolumn{3}{|l|}{ Labour market: } \\
\hline Tunisia & 109 & 1.5 & Working (Ref.) & 3840 & 52.6 \\
\hline Dominican Republic & 69 & 1.0 & Looking for a job & 1155 & 15.8 \\
\hline Brazil & 126 & 1.7 & Out of labour force & 2312 & 31.6 \\
\hline Ecuador & 167 & 2.3 & \multicolumn{3}{|l|}{ Education: } \\
\hline \multirow[t]{12}{*}{ Peru } & 187 & 2.6 & \multicolumn{3}{|l|}{ Low secondary } \\
\hline & & & school (Ref.) & 2796 & 38.3 \\
\hline & & & Vocational school & 1207 & 16.5 \\
\hline & & & High secondary school & 2259 & 30.9 \\
\hline & & & \multicolumn{2}{|l|}{ Italian proficiency: } & 14.3 \\
\hline & & & Good & 6368 & 87.1 \\
\hline & & & Bad & 939 & 12.9 \\
\hline & & & \multicolumn{3}{|l|}{ Religious-service attendance: } \\
\hline & & & Sometimes (Ref.) & 2228 & 30.5 \\
\hline & & & Never & 2928 & 40.1 \\
\hline & & & Often & 1828 & 25.0 \\
\hline & & & Missing & 323 & 4.4 \\
\hline
\end{tabular}

Source: Own calculation based on ISTAT survey "Social condition and integration of foreign citizens" 2011-12 
Tab. A2: Akaike's information criterion and Bayesian information criterion for models including only one variable

\begin{tabular}{lllrrrr}
\hline Model & Obs & II(null) & II(model) & df & AIC & BIC \\
\hline Previous children & 7,307 & $-10,650$ & $-9,917$ & 16 & 19,866 & 19,977 \\
Country of birth & 7,307 & $-10,650$ & $-9,930$ & 120 & 20,100 & 20,928 \\
Gender equity & 7,307 & $-10,650$ & $-10,522$ & 8 & 21,061 & 21,116 \\
Marital status & 7,307 & $-10,650$ & $-10,548$ & 12 & 21,119 & 21,202 \\
Religious-service attendance & 7,307 & $-10,650$ & $-10,566$ & 16 & 21,165 & 21,275 \\
Age interview & 7,307 & $-10,650$ & $-10,577$ & 8 & 21,171 & 21,226 \\
Age interview squared & 7,307 & $-10,650$ & $-10,583$ & 8 & 21,183 & 21,238 \\
Education & 7,307 & $-10,650$ & $-10,577$ & 16 & 21,187 & 21,297 \\
Age arrival & 7,307 & $-10,650$ & $-10,601$ & 8 & 21,218 & 21,274 \\
Labour market & 7,307 & $-10,650$ & $-10,605$ & 12 & 21,233 & 21,316 \\
Duration of stay & 7,307 & $-10,650$ & $-10,619$ & 8 & 21,255 & 21,310 \\
Language proficiency & 7,307 & $-10,650$ & $-10,628$ & 8 & 21,272 & 21,327 \\
Stability of presence & 7,307 & $-10,650$ & $-10,636$ & 8 & 21,288 & 21,344 \\
\hline
\end{tabular}

Note: Obs: Observations; II(null): log likelihood for the null model; II(model): log likelihood for the full model; df: degree of freedom; AIC: Akaike's information criterion; BIC: Bayesian information criterion.

Source: Own calculation based on ISTAT survey "Social condition and integration of foreign citizens" 2011-12 
Tab. A3: Relative risk ratios (RRR) of personal ideal number of children compared to origin country. The reference category is "equal". In the model we control for age at arrival, duration of stay, gender beliefs, and country of birth

\begin{tabular}{|c|c|c|c|c|}
\hline & $\begin{array}{c}\text { Lower than } \\
\text { in the origin } \\
\text { country }\end{array}$ & $\begin{array}{l}\text { Higher than } \\
\text { in the origin } \\
\text { country }\end{array}$ & $\begin{array}{l}\text { Up to } \\
\text { God }\end{array}$ & $\begin{array}{l}\text { I don't } \\
\text { know }\end{array}$ \\
\hline \multicolumn{5}{|l|}{ Previous children: $\operatorname{Ref}=0$} \\
\hline 1 & $1.22^{*}$ & 1.04 & $0.67^{* *}$ & $0.61 * * *$ \\
\hline 2 & $0.24 * * *$ & 1.22 & $0.27 * * *$ & $0.15^{* * *}$ \\
\hline 3 & $0.02 * * *$ & $16.09 * * *$ & $0.18^{* * *}$ & $0.14 * * *$ \\
\hline \multicolumn{5}{|c|}{ Marital status: Ref $=$ Never been married } \\
\hline Married & $0.76^{* *}$ & $0.72^{*}$ & $0.64^{* *}$ & $0.58^{* * *}$ \\
\hline Separated/widowed/divorced & 0.84 & 0.98 & $0.68^{*}$ & $0.75^{*}$ \\
\hline Age at interview & $1.17 * * *$ & 1.09 & $1.31 * * *$ & $1.27^{* * *}$ \\
\hline Age at interview squared & $1.00^{*}$ & $1.00^{*}$ & $1.00 * * *$ & $1.00 * * *$ \\
\hline \multicolumn{5}{|c|}{ Stability of the presence: $\operatorname{Ref}=$ Stable } \\
\hline Circular & $0.69 *$ & 1.13 & 1.29 & 0.83 \\
\hline \multicolumn{5}{|c|}{ Education: Ref = Low secondary school } \\
\hline Vocational school & 1.00 & 0.82 & $0.72 *$ & $1.22 *$ \\
\hline High secondary school & 1.10 & 0.84 & 1.04 & $0.75^{* *}$ \\
\hline Post-secondary education & 0.86 & $0.64^{* *}$ & $0.73^{*}$ & $0.48^{* * *}$ \\
\hline \multicolumn{5}{|l|}{ Italian proficiency: $\operatorname{Ref}=$ Good } \\
\hline Bad & 1.10 & 1.20 & 1.16 & 0.96 \\
\hline \multicolumn{5}{|c|}{ Religious-service attendance: $\operatorname{Ref}=$ Sometimes } \\
\hline Never & $0.78^{* *}$ & $0.82^{*}$ & 0.89 & 1.05 \\
\hline Often & 0.87 & 1.23 & 1.02 & 1.21 \\
\hline Missing & 0.92 & 0.82 & 1.38 & $3.49 * * *$ \\
\hline \multicolumn{5}{|c|}{ Labour market condition: Ref $=$ Working } \\
\hline Looking for a job & 1.05 & 1.02 & $0.75^{*}$ & 1.15 \\
\hline Out of labour force & $0.81 *$ & 0.86 & 1.06 & $1.42^{* * *}$ \\
\hline \multicolumn{5}{|l|}{ Age at arrival: $\operatorname{Ref}=<16$} \\
\hline $16-20$ & $0.728^{*}$ & 0.778 & $0.658 *$ & $0.580^{* *}$ \\
\hline $21+$ & $0.607^{*}$ & 0.719 & 0.665 & $0.463^{* * *}$ \\
\hline \multicolumn{5}{|l|}{ Duration of stay: $\operatorname{Ref}=<6$ years } \\
\hline $6-10$ years & 1.035 & 1.009 & $0.796^{*}$ & 0.939 \\
\hline $11+$ years & 0.880 & 1.174 & 0.762 & 0.877 \\
\hline \multicolumn{5}{|l|}{ Gender equity: $\operatorname{Ref}=\mathrm{No}$} \\
\hline yes & $0.828^{* *}$ & 1.154 & $0.270 * * *$ & $0.503^{* * *}$ \\
\hline \multicolumn{5}{|l|}{ Country of Birth: Ref Albania } \\
\hline EU15 and ODCs & 1.31 & $0.59 *$ & 1.41 & 1.31 \\
\hline Other Europe & $2.37 * * *$ & 0.73 & 1.08 & $1.77^{* *}$ \\
\hline Other Africa & $26.86^{* * *}$ & $0.20 * * *$ & $3.70 * * *$ & $7.27^{* * *}$ \\
\hline Other Latin America & $2.35^{* * *}$ & 0.66 & $2.11 *$ & 1.11 \\
\hline Other Asia & $13.99 * * *$ & $0.43^{*}$ & $4.94 * * *$ & $2.49 * *$ \\
\hline Bulgaria & $16.78^{* * *}$ & $0.26^{* * *}$ & $4.01 * * *$ & $3.11 * * *$ \\
\hline France & $0.47^{*}$ & 0.60 & 0.85 & 0.86 \\
\hline
\end{tabular}


Tab. A3: Continuation

\begin{tabular}{|c|c|c|c|c|}
\hline & $\begin{array}{c}\text { Lower than } \\
\text { in the origin } \\
\text { country }\end{array}$ & $\begin{array}{l}\text { Higher than } \\
\text { in the origin } \\
\text { country }\end{array}$ & $\begin{array}{l}\text { Up to } \\
\text { God }\end{array}$ & $\begin{array}{l}\text { I don't } \\
\text { know }\end{array}$ \\
\hline Germany & 1.19 & 1.47 & 0.63 & 1.13 \\
\hline Poland & 0.76 & 1.54 & 1.51 & 1.32 \\
\hline Romania & 0.91 & $0.63^{*}$ & 1.15 & 0.86 \\
\hline Ukraine & 1.12 & 0.85 & $0.61 *$ & 1.24 \\
\hline Russia & 1.08 & 1.25 & 0.92 & 0.55 \\
\hline Macedonia & $11.35^{* * *}$ & $0.15^{* * *}$ & $4.49 * * *$ & $3.81 * * *$ \\
\hline Moldova & $17.34 * * *$ & $0.21 * * *$ & $3.73 * * *$ & $4.00^{* * *}$ \\
\hline Kosovo & $13.52 * * *$ & $0.42^{*}$ & $4.50 * * *$ & 1.87 \\
\hline Bangladesh & 0.45 & 1.53 & 1.30 & 1.14 \\
\hline Sri Lanka & $21.88^{* * *}$ & $0.10^{* *}$ & $9.47 * * *$ & $4.39 * * *$ \\
\hline China & 0.96 & 1.34 & $1.75^{*}$ & 1.03 \\
\hline Philippines & $21.03^{* * *}$ & $0.39 *$ & $6.42 * * *$ & $6.74^{* * *}$ \\
\hline India & 0.56 & 0.79 & 1.56 & 0.84 \\
\hline Ghana & $42.16^{* * *}$ & $0.06^{* * *}$ & $8.39 * * *$ & 2.56 \\
\hline Morocco & $9.87^{* * *}$ & $0.28^{* * *}$ & $4.14^{* * *}$ & $2.54^{* * *}$ \\
\hline Nigeria & $197.47 * * *$ & 0.00 & $85.46 * * *$ & $48.38^{* * *}$ \\
\hline Senegal & $27.95^{* * *}$ & $0.18^{* *}$ & $8.90 * * *$ & $3.97^{* *}$ \\
\hline Tunisia & $10.25^{* * *}$ & $0.10 * * *$ & $2.52^{*}$ & $2.55^{* *}$ \\
\hline Dominican Republic & $4.93^{* * *}$ & $0.35^{*}$ & 0.90 & 1.93 \\
\hline Brazil & 1.08 & 1.44 & 0.80 & 0.86 \\
\hline Ecuador & $16.61 * * *$ & $0.24 * * *$ & 2.09 & $4.36^{* * *}$ \\
\hline Peru & 0.90 & $1.98^{* *}$ & $0.42^{*}$ & 1.06 \\
\hline Constant & 0.48 & $0.02 * * *$ & $0.04 * * *$ & $0.07 * * *$ \\
\hline Log likelihood & \multicolumn{4}{|c|}{$-8,503.53$} \\
\hline
\end{tabular}

*** $p<0.001 * * p<0.005 * p<0.05$

Note: Up to God (UtG), I don't know (IDK)

Source: Own calculation based on ISTAT survey "Social condition and integration of foreign citizens" 2011-12

Table A3 show that women with parity 0 have a higher RRR of giving non-numeric responses compared to the women that have a similar personal ideal family size in Italy compared to their origin country. The RRR of having lower ideals decreases with the increases of the parity and, conversely, the risk of having larger ideals than the origin country average increases if the women already have three or more children. Never-married women have a higher RRR of having the same personal ideal family size of their origin country. Women with a more dynamic (circular/interrupted) pattern of migration have a lower RRR of having fewer children than the norm in their origin country. No statistical effect is found for Italian language proficiency. Lack of religious service attendance decreases both the risk of having lower or higher numbers of children than the norm in the origin country. 


\section{Comparative Population Studies}

WWW.comparativepopulationstudies.de

ISSN: 1869-8980 (Print) - 1869-8999 (Internet)

\section{Published by}

Prof. Dr. Norbert F. Schneider

Federal Institute for Population Research D-65180 Wiesbaden / Germany

\section{(cc) BY-SA}

2018

\section{Managing Editor}

Dr. Katrin Schiefer

\section{Copy Editor}

Dr. Evelyn Grünheid

Dr. Katrin Schiefer

\section{Editorial Assistant}

Beatriz Feiler-Fuchs

Wiebke Hamann

\section{Layout \\ Beatriz Feiler-Fuchs \\ E-mail:cpos@bib.bund.de}

\section{Scientific Advisory Board}

Karsten Hank (Cologne)

Michaela Kreyenfeld (Berlin)

Marc Luy (Vienna)

Peter Preisendörfer (Mainz)

Nikola Sander (Wiesbaden)

Zsolt Spéder (Budapest)

Rainer Wehrhahn (Kiel)

\section{Board of Reviewers}

Martin Abraham (Erlangen)

Laura Bernardi (Lausanne)

Hansjörg Bucher (Bonn)

Claudia Diehl (Konstanz)

Andreas Diekmann (Zurich)

Gabriele Doblhammer-Reiter (Rostock)

Jürgen Dorbritz (Wiesbaden)

Anette Eva Fasang (Berlin)

E.-Jürgen Flöthmann (Bielefeld)

Alexia Fürnkranz-Prskawetz (Vienna)

Beat Fux (Salzburg)

Joshua Goldstein (Berkeley)

Sonja Haug (Regensburg)

Hill Kulu (Liverpool)

Aart C. Liefbroer (The Hague)

Kurt Lüscher (Konstanz)

Emma Lundholm (Umeå)

Nadja Milewski (Rostock)

Dimiter Philipov (Vienna)

Roland Rau (Rostock)

Tomáš Sobotka (Vienna)

Jeroen Spijker (Barcelona)

Olivier Thévenon (Paris)

Helga de Valk (Brussels)

Heike Trappe (Rostock)

Michael Wagner (Cologne) 